\title{
Benthic macrofaunal communities of three sites in San Francisco Bay invaded by hybrid Spartina, with comparison to uninvaded habitats
}

\author{
Carlos Neira $^{1, *}$, Lisa A. Levin ${ }^{1}$, Edwin D. Grosholz ${ }^{2}$ \\ ${ }^{1}$ Integrative Oceanography Division, Scripps Institution of Oceanography, La Jolla, California 92093-0218, USA \\ ${ }^{2}$ Department of Environmental Science and Policy, One Shields Avenue, University of California, Davis, California 95616, USA
}

\begin{abstract}
A hybrid cordgrass, formed from a cross between Spartina alterniflora (Atlantic cordgrass) and $S$. foliosa (Pacific cordgrass), has recently spread within the intertidal zone of south San Francisco Bay. Sediment properties and macroinfaunal community structure were compared in patches invaded by Spartina hybrid and adjacent uninvaded patches at 3 sites in San Francisco Bay ( 2 tidal flats and 1 Salicornia marsh). We hypothesized that (1) sediments vegetated by Spartina hybrid would have reduced sediment grain size, higher organic matter content, lower redox potential, lower salinity and reduced microalgal biomass relative to adjacent unvegetated tidal flat sediments, and (2) that differences in the sediment environment would correspond to changes in the infaunal invertebrate community structure and feeding modes. We observed $75 \%$ lower total macrofaunal density and lower species richness in Spartina-vegetated sediments at Elsie Roemer (30 yr old invasion) than in an adjacent unvegetated tidal flat. This was due to lower densities of surface-feeding amphipods, bivalves, cirratulid and spionid polychaetes. The proportional representation of subsurface-deposit feeders was greater in Spartina patches than in unvegetated sediments. At a more recently invaded site (Roberts Landing; $15 \mathrm{yr}$ invasion), Spartina patches differed from tidal flat sediments in composition, but not in abundance. Native (Salicornia) and Spartina patches exhibited similar sediment properties at San Mateo, where the Spartina hybrid invaded 8 to 10 yr earlier. No differences were detected in densities or proportions of surface- or subsurface-deposit feeders, but the proportion of carnivores/omnivores and grazers increased in the hybrid-invaded patches. These studies suggest that the invasive Spartina hybrid in south San Francisco Bay can have differing effects on sediment ecosystems, possibly depending on the location, age, or type of habitats involved.
\end{abstract}

KEY WORDS: Benthos $\cdot$ Biodiversity $\cdot$ Cordgrass $\cdot$ Deposit feeding $\cdot$ Infauna $\cdot$ Macrobenthos $\cdot$ Plant invasion $\cdot$ Salt marsh $\cdot$ Redox potential

\section{INTRODUCTION}

The presence of plants in tidal settings affects ecosystem-level processes such as nutrient cycling and productivity by altering hydrographic properties, disturbance frequency and sedimentation rates (Bertness 1988, De la Cruz et al. 1989, Leonard \& Luther 1995). The sediments, microbes, infaunal invertebrates and marsh macrophytes of coastal wetlands form a highly integrated system whose ecological functions (e.g. decomposition, nutrient cycling, trophic support, baffling) provide key ecosystem services such as nursery support, water filtration, and storm protection (Snelgrove 1999, Snelgrove et al. 1997, 2000). The ability of vascular plant presence, cover, density and composition to influence the structure and function of wetlands has been widely recognized (Leonard \& Luther 1995, Levin \& Talley 2000). Plant effects on salt marsh sediments and biota have been elucidated through investigations of newly restored ecosystems (Levin et al. 1996, Craft \& Sacco 2003, Stanczak \& Keiper 2004) and by tracking changes following plant invasion (Posey 1988, Posey et al. 1993, Talley \& Levin 2001).

Introduction of non-indigenous plant species into tidal wetlands has occurred worldwide (Ruiz et al. 1997, 
Adam 2002). By controlling, space and food resources available to other organisms through alterations in biotic, physical and biogeochemical sedimentary properties (e.g. Levin \& Talley 2000, Talley \& Levin 2001), vascular plants invading tidal habitats typically act as ecosystem engineers (Jones et al. 1994, Crooks 2002).

Plant invasions of tidal habitats are widespread on the east and west coasts of North America and in Europe. The purple loosestrife Lythrum salicaria has replaced native species in wetlands of Canada and Washington State (Thompson et al. 1987). The reed grass Phragmites australis has invaded large areas of midAtlantic tidal Spartina alterniflora marsh (Leonard et al. 2002), and the Japanese eelgrass Zostera japonica has invaded extensive mudflat areas of Oregon and Washington (Posey 1988). On the west coast of North America, there are 4 non-native species of Spartina (S. alterniflora, S. anglica, S. patens, and S. densiflora) and 1 native species, S. foliosa (Daehler \& Strong 1996, Ayres et al. 2004). The smooth cordgrass $S$. alterniflora, native to the east coast of North America and the Gulf of Mexico, is found in Willapa Bay, Washington State and in San Francisco Bay, California (Spicher \& Josselyn 1985, Daehler \& Strong 1997) as well as Tasmania (Australia) (Hedge \& Kriwoken 2000) and China (Chung 1990).

Spartina alterniflora was first introduced into San Francisco Bay, California, USA as part of experimental marsh restoration projects by the US Army Corps of Engineers (USACE) in the early 1970s. Early on, Callaway \& Josselyn (1992) recognized the competitive superiority and greater ecological range of the exotic Spartina relative to the native ( $S$. foliosa) and predicted the native $S$. foliosa would be outcompeted and eliminated. Soon after its introduction, $S$. alterniflora hybridized naturally with the native cordgrass $S$. foliosa (Daehler \& Strong 1997), producing a more vigorous plant, which has since invaded numerous marshes in south San Francisco Bay (Ayres et al. 1999). Compared with their parental species, the hybrids are taller, grow at a greater stem density, and have a denser root system (Ayres et al. 2003). At the time of writing, S. alterniflora and its hybrids covered ca. 190 ha of tidal flat and salt marsh in San Francisco Bay, mainly in south Bay.

Effects of plant invasion on sediment properties, plant and macrofaunal composition are not consistent among sites. Marsh sediments invaded by Phragmites australis along the lower Connecticut River estuary, exhibited much lower organic matter content, greater litter accumulation and higher chlorophyll a concentrations than the uninvaded areas (Talley \& Levin 2001). Also, macro-infaunal densities were lower and the assemblage shifted from dominance by burrowing oligochaetes and midges to tube-building and surfacefeeding forms. In Spartina anglica and S. foliosa marshes, lower diversity or density and different macrofaunal composition have been reported relative to unvegetated areas (Frid \& James 1989, Jackson 1985, Levin et al. 1998). However, in SE Brazil, higher macrofaunal density and species richness were observed in $S$. alterniflora habitats relative to unvegetated areas (Lana \& Guiss 1991). S. alterniflorainvaded mudflats of Willapa Bay, Washington State, USA exhibited higher macrofaunal densities than than uninvaded areas, and an increase in subsurface, deposit-feeding taxa (e.g. Capitella) occurred in older meadows of S. alterniflora (Zipperer 1996).

In this study we compare sediment properties and macroinfaunal community structure in 3 paired Spartina hybrid-invaded and adjacent uninvaded habitats of south San Francisco Bay. In 2 locations, unvegetated tidal flats are being invaded by Spartina hybrid. In a third, a Salicornia virginica marsh is being invaded by Spartina hybrid. Our general understanding of how macrophytes influence salt marsh sediments and infauna (reviewed in Levin \& Talley 2000) guided the sampling. We hypothesized that (1) Spartina hybridvegetated sediments would have finer sediment grain size, higher organic matter content, lower redox potential, lower salinity and reduced microalgal biomass, relative to adjacent unvegetated tidal flat sediments, and (2) that differences in the sediment environment would correspond to changes in the macroinfaunal community structure and feeding modes. Observations of sediment and faunal differences associated with Spartina hybrid habitat of San Francisco Bay may provide valuable information about the role of vascular plants in structuring marsh ecosystems, as well as baseline data against which to document further change. We focused on the macroinfaunal community because it represents an important trophic link between primary production derived from the marsh and higher consumers (Currin et al. 1995, Kreeger \& Newell 2000). Changes in abundance, composition, and lifestyles of infaunal organisms, and hence their accessibility to consumers, reflect the extent and efficiency of trophic functions in coastal wetlands.

\section{MATERIALS AND METHODS}

Study locations. Sampling was conducted in June 2001 at 3 sites in south San Francisco Bay, California, USA (Fig. 1). The northernmost site, Elsie Roemer, lies in the city of Alameda along the shoreline adjacent to Elsie Roemer Bird Sanctuary $\left(37^{\circ} 45^{\prime} 35^{\prime \prime} \mathrm{N}\right.$, $122^{\circ} 28^{\prime} 48^{\prime \prime}$ W). Spartina-hybrid first invaded the tidal flat here about $30 \mathrm{yr}$ ago. The invaded area forms a continuous meadow of Spartina hybrid which borders the open tidal flat (Fig. 1). In addition, there are some islands of Spartina hybrid scattered 20 to $50 \mathrm{~m}$ from the 


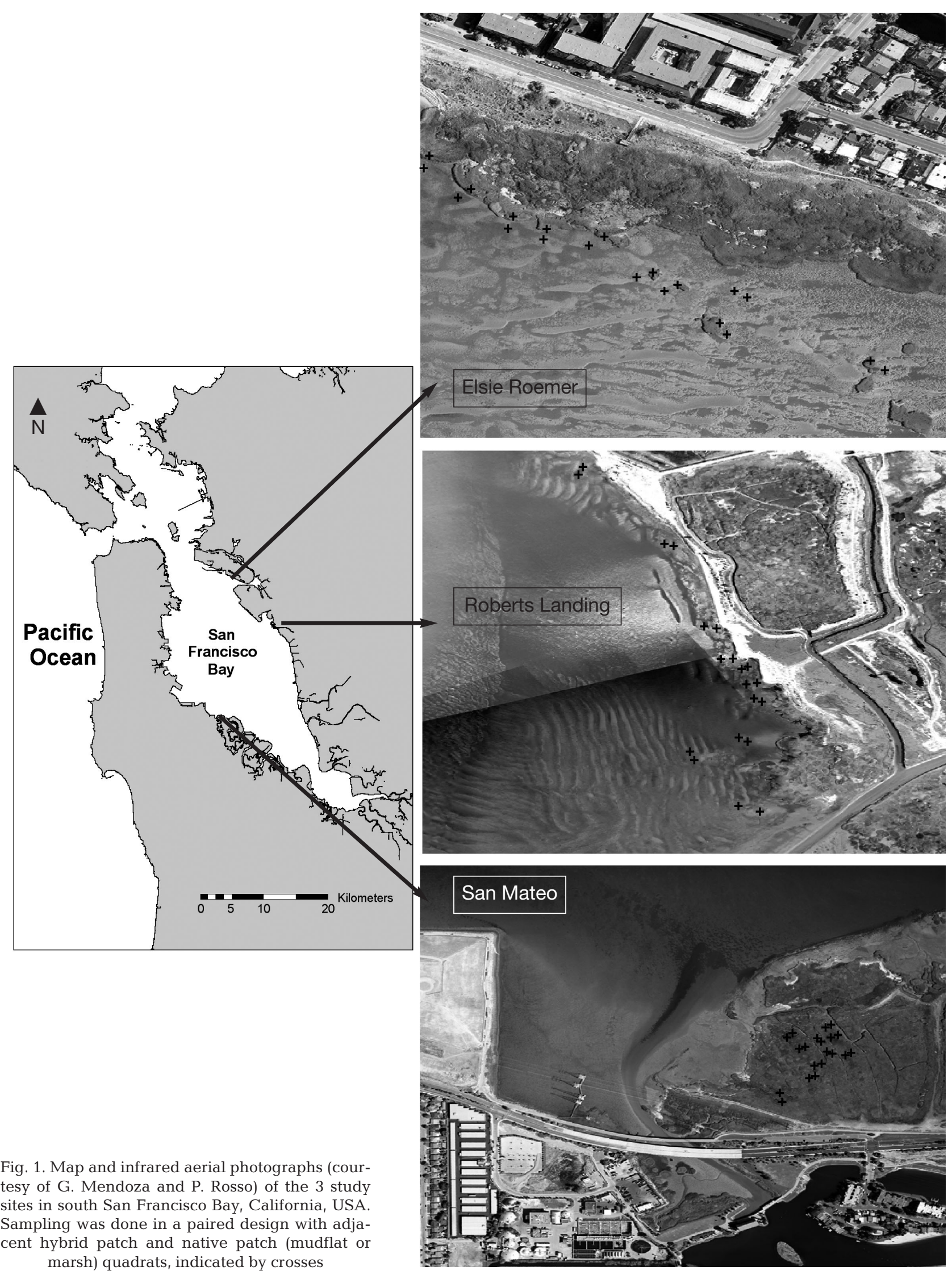


edge of the meadow (Fig. 1). Both meadows and islands were sampled.

Approximately $12 \mathrm{~km}$ to the south, we sampled Roberts Landing ( $\left.37^{\circ} 40^{\prime} 13^{\prime \prime} \mathrm{N}, 122^{\circ} 09^{\prime} 42^{\prime \prime} \mathrm{W}\right)$, a long exposed shoreline, situated north of Hayward Regional Shoreline, near San Lorenzo Creek. The invasion involves 10 to 15 yr old Spartina patches of various heights and densities scattered along the shoreline within the tidal flat. Genetic characterization of Spartina from this site using RAPD markers (Random Amplified Polymorphic DNA; D. Strong, D. Ayres pers. comm.) revealed the presence of Spartina hybrids and the native $S$. foliosa co-existing side by side. Sampling included both tall (Spartina hybrid) and short (native $S$. foliosa) vegetated patches.

We sampled San Mateo marsh, a vegetated site on the western side of south San Franciso Bay $\left(37^{\circ} 41^{\prime} 11^{\prime \prime} \mathrm{N}, 122^{\circ} 17^{\prime} 06^{\prime \prime} \mathrm{W}\right)$ (Fig. 1) where the perennial Salicornia virginica is the dominant vascular plant. At higher tidal elevations, the macrophytes Distichlis spicata, Frankenia salina, Triglochin maritima, and Grindelia sp. are also present. The invasion of Salicornia-dominated areas by Spartina hybrid in San Mateo is estimated to be relatively recent ( 8 to $10 \mathrm{yr}$ ago). Large round patches (40 to $240 \mathrm{~m}^{2}$ ) have been converted from Salicornia-inhabited areas into monotypic swards of Spartina hybrid, with about $50 \%$ cover by Spartina hybrids in 1999 (Ayres et al. 2004).

Sampling design and field methods. A pair-wise sampling design was used to compare sediment and biotic properties of hybrid-invaded patches to adjacent tidal flats (Elsie Roemer, Roberts Landing) and to Salicornia marsh (San Mateo). A total of 10 replicate blocks separated by about 20 to $50 \mathrm{~m}$ from one another were established along the shoreline (Elsie Roemer and Roberts Landing) or in the marsh (San Mateo). Within each block, we sampled 1 hybridinvaded quadrat $(0.5 \times 0.5 \mathrm{~m})$ and 1 control patch in the adjacent (ca. $5 \mathrm{~m}$ away) open tidal flat (Elsie Roemer, Roberts Landing) or Salicornia meadow (San Mateo). At Elsie Roemer, the blocks included continuous meadow and islands of Spartina hybrid (5 each) (Fig. 1). At Roberts Landing, 6 blocks were established along the shoreline, and an additional 4 were Spartina islands (Fig. 1). One $0.25 \mathrm{~m}^{2}$ quadrat was designated haphazardly within the plant-invaded area and within the open tidal flat of the corresponding block.

Within each quadrat, measurements were made of total Spartina (or Salicornia) stem density, average stem height $(n=15)$ for Spartina hybrid plants, percent open space (space between culms), percent cover for each plant species, and percent cover of green algae and/or microalgae mat. Light penetration was measured above and below the hybrid canopy or at the sediment surface in unvegetated quadrats using a LICOR spherical sensor (LI-192SA) with a LI-1400 data logger.

Pore water salinity was measured in each quadrat from the top $3 \mathrm{~cm}$ of sediment. The sediment was squeezed against a Whatman filter paper inside a $10 \mathrm{~cm}^{3}$ syringe and the salinity was measured with a hand-held salinity refractometer. Small cores were collected within each quadrat for determination of benthic chlorophyll $a$ $\left(1.13 \mathrm{~cm}^{2} \times 5 \mathrm{~mm}\right.$ depth) and of pigment composition $\left(0.56 \mathrm{~cm}^{2} \times 5 \mathrm{~mm}\right)$ using high performance liquid chromatography (HPLC). An additional core $\left(1.13 \mathrm{~cm}^{2} \times\right.$ $1 \mathrm{~cm}$ ) was used to determine water content and porosity. Cores $\left(18.1 \mathrm{~cm}^{2}, 0\right.$ to $\left.6 \mathrm{~cm}\right)$ were collected for analyses of macrofauna and belowground plant biomass (from the same sediment core) and sediment properties including particle size and organic matter content. Macrofaunal cores were preserved in $8 \%$ buffered formalin with rose bengal. Samples for HPLC were put in glass vials and kept at $-80^{\circ} \mathrm{C}_{i}$ the remaining sediment samples were kept frozen at $-20^{\circ} \mathrm{C}$ until further analysis. Sediment redox potential was measured at the 3 study sites at 1 and $5 \mathrm{~cm}$ depth in the sediment column with a portable Mettler Toledo $\mathrm{mV}$-meter. In order to better examine redox depth gradients at the Spartina-vegetated and tidal flat habitats of Elsie Roemer, a more detailed redox depth profile was generated by gradually inserting a single electrode (Mettler Toledo InLab ${ }^{\oplus}$ ) at $1 \mathrm{~cm}$ intervals through the sediment. The $\mathrm{mV}$ readings were corrected to the standard hydrogen electrode by adding +207 mV (Giere et al. 1988).

Information about below-ground sediment structure of vegetated and unvegetated sediments in Elsie Roemer and Roberts Landing was obtained by X-raying 2 replicate slabs of sediments collected with a plexi-glass corer $(3 \times 12 \times 18 \mathrm{~cm}$ deep $)$. X-radiography was performed using ACOMA's model PX-20N portable X-ray unit.

Tidal elevations for each block at each location in vegetation and on mudflats were surveyed with a Topcon Total Station (Model GTS-603). Tidal elevations for all field sites were referenced to NOAA tidal benchmarks (using NAVD 88) that had been resurveyed within the last 15 yr. At least 2 tidal benchmarks were located within the vicinity of each site and we surveyed benchmarks relative to each other to check for accuracy.

Laboratory methods. Sediment cores for analysis of macrofauna and below ground plant material were washed through a $0.3 \mathrm{~mm}$ mesh. Animals retained on the sieve were sorted, counted and identified to the lowest taxonomic level possible using a dissecting microscope and, when necessary, compound microscope. Feeding modes were assigned based on Fauchald \& Jumars (1979). Below-ground plant detritus material $(\geq 0.3 \mathrm{~mm}$ ) was removed from the macrofaunal cores (upper $6 \mathrm{~cm}$ ), dried at $60^{\circ} \mathrm{C}$ and weighed on an analytical balance. Because in San Mateo the 
Spartina hybrid was already established as monospecific patches inside the Salicornia meadow, all root material within the core was assumed to be from Spartina plants. Sediment samples for grain size and organic matter content analysis were homogenized and wet-sieved through a $2 \mathrm{~mm}$ mesh to remove large shells and roots. A portion of sediment was digested with hydrogen peroxide and wet sieved through a $63 \mu \mathrm{m}$ mesh for particle size analysis. Both fractions of the sample $(\geq 63$ and $<63 \mu \mathrm{m})$ were dried at $60^{\circ} \mathrm{C}$ and weighed to determine percent sand. Total organic matter content was determined by weight loss of dried sediment after ignition at $500^{\circ} \mathrm{C}$ for $4 \mathrm{~h}$. Water content and porosity were determined by weight loss after drying a known volume of sediment and assuming a sediment and water density of $2.65 \mathrm{~g} \mathrm{~cm}^{-3}$ (quartz) and $1.025 \mathrm{~g} \mathrm{~cm}^{-3}$, respectively (Buchanan 1984).

Chlorophyll a concentration was determined spectrophotometrically from sediment samples extracted with $90 \%$ acetone according to Plante-Cuny (1973). Because our study system was limited to the sediment ecosystem, the chlorophyll $a$ is an estimate of living microalgal biomass from the sediment not including algae attached to plant stems. More detailed pigment composition was analyzed using HPLC techniques (Brotas \& Plante-Cuny 1998) following extraction with $90 \%$ acetone. Pigments were identified based on comparisons of their retention times with single species standards. Analysis for differences in microphytobenthos composition was based on the abundances of chlorophyll a (all oxygenic photoautotrophs), zeaxanthin (cyanobacteria), and lutein (green algae and vascular plants). Fucoxanthin was used as an indicator of diatoms because microscopic observations revealed the absence or very low amounts of brown algae and dinoflagellates, the other algae containing this pigment. Changes in microbial mat community composition was estimated by the ratio of zeaxanthin to fucoxanthin, which reflects the abundance of cyanobacteria relative to diatoms (Pinckney et al. 1995).

Statistical analysis. Matched-pairs t-tests (using JMP 4.0 statistical software) were used to test for significant differences in macrofauna, sediment properties, and environmental variables between invaded and uninvaded habitats. One-way ANOVA with an a posteriori Tukey's HSD test was used to examine between-site differences in sediment and faunal properties. One standard error (SE) about the mean is presented with mean data unless otherwise indicated. All proportion data were arcsin-square-root transformed prior to ANOVA and then back-transformed for presentation in graphs.
Similarities and differences in macrofaunal communities were explored using non-metric multidimensional scaling (MDS), based on Bray-Curtis similarity indices. Stress values indicate how well the solution (2-dimensional MDS plot) reflect the similarities among cores. Values $<0.1$ are good and $<0.2$ are useful (Clarke 1993). Pair-wise comparisons for significant differences in macrofaunal composition between habitats (and sites) were made using Analysis of Similarity (ANOSIM) (Clarke 1993). Similarity Percentage (SIMPER) analyses were used to determine the percent of dissimilarity (or similarity) of samples and the particular taxa responsible for differences between groups (Clarke 1993). These multivariate analyses (MDS, ANOSIM, SIMPER) were run using PRIMER (Plymouth Marine Laboratory, Clarke 1993, Clarke \& Warwick 1994) on square-roottransformed, unstandardized data.

\section{RESULTS}

\section{Vegetation and algae characteristics}

The former open tidal flat sediments of Elsie Roemer and Roberts Landing were converted to a grass landscape by the invasive Spartina hybrid (Fig. 1). The invaded tidal flat habitats had higher shoot density at Roberts Landing $\left(450 \pm 60\right.$ plants $\left.\mathrm{m}^{-2}\right)$ than Elsie Roemer $\left(292 \pm 19\right.$ plants $\left.\mathrm{m}^{-2}\right)\left(t_{18}=2.4, \mathrm{p}=0.025\right)$. At both sites tall stems formed a compact below-ground root matrix and a dense canopy (Fig. 2). The shoot density of Spartina-hybrid patches growing in San Mateo (269 \pm 35 plants $\mathrm{m}^{-2}$ ) was significantly lower than shoot density in the native Salicornia virginica habitat (698 \pm 115 plants $\left.\mathrm{m}^{-2}\right)\left(t_{18}=3.6, \mathrm{p}=0.002\right)$, but no differences were observed in plant height, percent cover and below-ground plant biomass between the Spartinainvaded and Salicornia-vegetated sediments (Fig. 3).

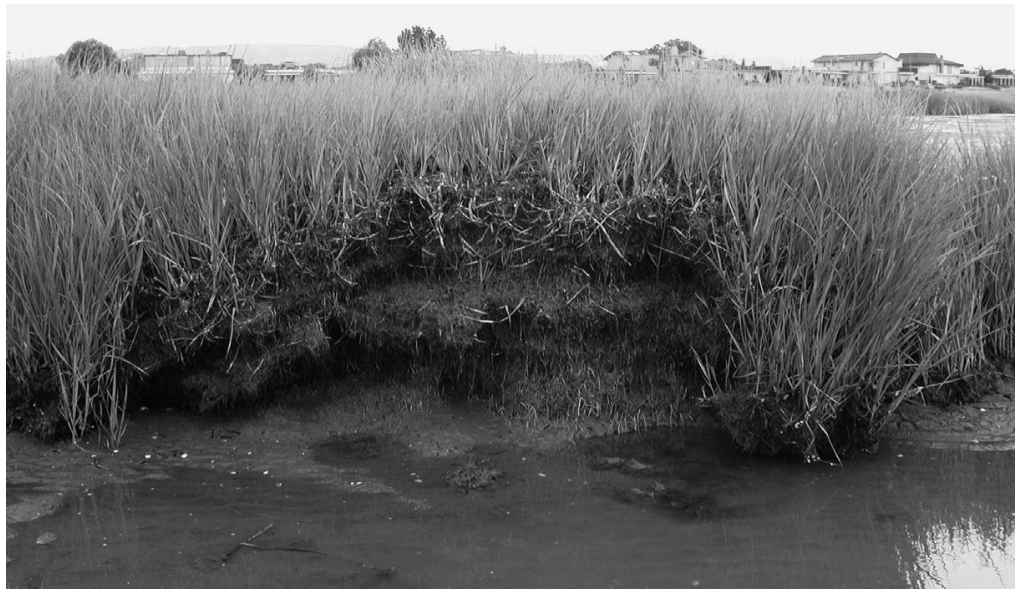

Fig. 2. Compact below-ground root matrix formed by Spartina hybrid at Elsie Roemer. (Photo by C.N., June 2001) 

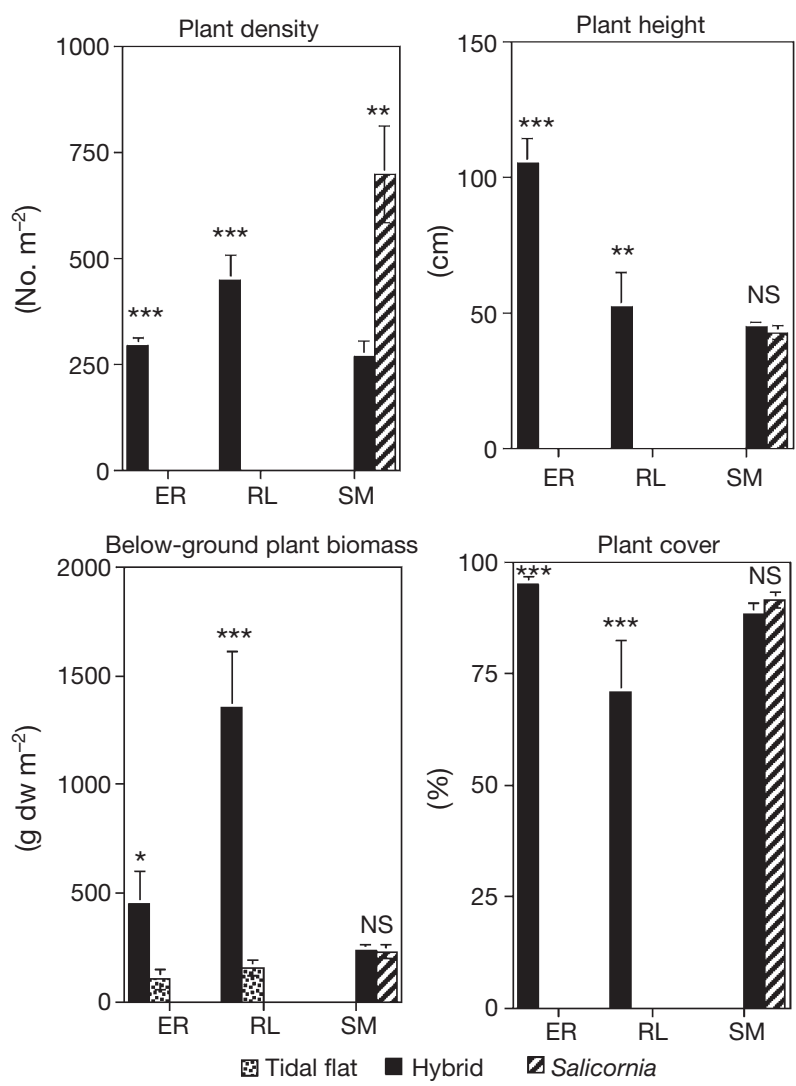

Fig. 3. Spartina properties at Elsie Roemer (ER), Roberts Landing (RL) and San Mateo (SM) in south San Francisco Bay. Values are mean \pm 1 SE. Asterisks indicate significant differences based on paired $t$-tests comparing invaded patches (Spartina hybrid) and uninvaded patches (tidal flat or Salicornia marsh). ${ }^{*} 0.01 \leq p<0.05,{ }^{*} 0.001 \leq p<0.01,{ }^{* * *} p<0.001$

\section{Microphytobenthos}

There were no significant differences in sediment microalgal biomass, as reflected by chlorophyll a concentration, between Spartina-invaded and uninvaded sediments at any of the 3 sites (Fig. 4). However, at Elsie Roemer we found higher chlorophyll a concentrations in sediments of the Spartina hybrid islands relative to the meadow ( $p=0.022$ ). At Roberts Landing, the diatom biomass, as indicated by the concentration of fucoxanthin, was significantly reduced in the hybrid-invaded habitat $\left(7.97 \pm 1.04 \mu \mathrm{g} \mathrm{cm}^{-2}\right)$ relative to the tidal flat $\left(13.34 \pm 1.33 \mu \mathrm{g} \mathrm{cm} \mathrm{cm}^{-2}\right)\left(t_{3.2}=18\right.$, $\mathrm{p}=0.005$ ). Concentrations of lutein (green algae and vascular plants) and zeaxanthin (cyanobacteria) did not differ between invaded and uninvaded habitats. There was considerable variability in the ratios of zeaxanthin to fucoxanthin among samples, indicating a highly patchy distribution of the microphytobenthos groups, but no differences in this ratio were detected between Spartina-invaded and uninvaded sediments at any site.

\section{Environmental and sediment properties}

Sediment properties in Spartina hybrid-invaded habitats differed relative to those of the adjacent unvegetated tidal flat sediments. Spartina-invaded patches in Roberts Landing were finer-grained $\left(t_{9}=2.4\right.$, $\mathrm{p}=0.042$ ), with higher organic matter content relative to uninvaded patches $\left(t_{9}=2.4, \mathrm{p}=0.05\right)$. However, in Elsie Roemer and San Mateo, these properties did not vary significantly among patch types (Fig. 4). Invaded sediments exhibited lower porewater salinities $\left(t_{9}=3.4\right.$, $\mathrm{p}=0.008$ ) at Elsie Roemer and Roberts Landing, but no major changes were observed in porosity (Fig. 4).

Spartina hybrid-invaded patches occurred $0.3 \mathrm{~m}$ higher in the intertidal than the adjacent tidal flats both at Elsie Roemer and Roberts Landing (Fig. 4). At Elsie Roemer, mean elevations $( \pm \mathrm{SE})$ of the vegetated area and tidal flat were $0.98 \pm 0.05 \mathrm{~m}$ and $0.64 \pm 0.06 \mathrm{~m}$ above mean lower low water (MLLW), respectively $\left(t_{18}=4.3\right.$, $\mathrm{p}=0.0005$ ) while at Roberts Landing, mean elevations of the vegetated area and tidal flat were $2.81 \pm 0.10 \mathrm{~m}$ and $2.54 \pm 0.03 \mathrm{~m}$ above MLLW, respectively $\left(t_{18}=4.4, \mathrm{p}=\right.$ 0.0003). Also, hybrid island sites at both Elsie Roemer (Fig. 2) and Roberts Landing showed higher elevations than the meadow. This may have been caused by erosion of surrounding tidal flat sediments (E.D.G. pers. obs.). At San Mateo, no significant difference in elevation was found between the hybrid-vegetated area $(1.99 \pm 0.02 \mathrm{~m}$ above MLLW) and the Salicornia meadow $\left(2.02 \pm 0.02 \mathrm{~m}\right.$ above MLLW) $\left(t_{18}=1.3, \mathrm{p}=0.203\right)$.

Light penetration was significantly lower (83 and $71 \%$, respectively, $\mathrm{p}<0.001)$ as was open space $(\mathrm{p}<$ 0.001 ) at the Spartina hybrid-vegetated sites (Elsie Roemer, Roberts Landing) relative to the unvegetated tidal flat sites. At San Mateo, the high number of plants as well as the dense canopy (about $90 \%$ cover) (Fig. 3) led to low light penetration and open space in both Spartina-invaded and Salicornia habitats (Fig. 4).

Redox potential, which is often used to quantify the degree of reduction or oxidation, and hence availability of nutrients, of wetland sediments (Gambrell \& Patrick 1978), differed slightly in Spartina hybridinvaded sediments relative to uninvaded sediment patches. In general, most sediments exhibited reduced conditions (Eh $<+100 \mathrm{mV}$, Meyer-Reil 1983) in the top 1 and $5 \mathrm{~cm}$ (Fig. 5A,B). Depth profiles of Eh made in Elsie Roemer revealed that sediments underlying stands of Spartina hybrid were more oxidized than uninvaded tidal flat habitats (Fig. 5C) $\left(t_{14}=6.4, \mathrm{p}<0.0001\right)$. Our Eh measurements down to $8 \mathrm{~cm}$ covered most of the rootmatrix zone and suggest that Spartina hybrid oxidizes the sediments around the roots and rhizomes.

X-radiographs of sediments in Elsie Roemer and Roberts Landing (tidal flat invasions) revealed dif- 

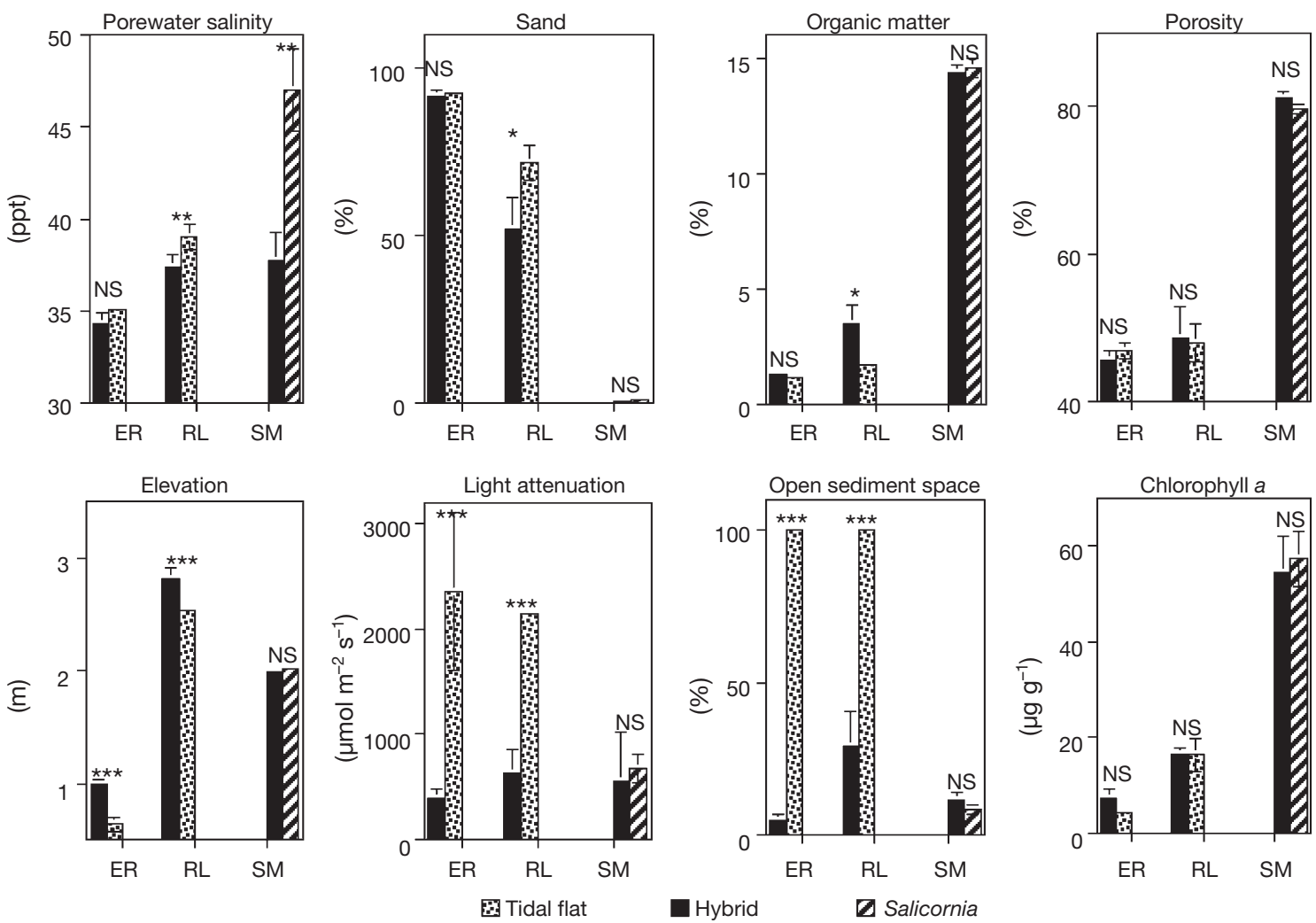

Fig. 4. Sediment properties and microalgal biomass (chl a) at Elsie Roemer (ER), Roberts Landing (RL) and San Mateo (SM) in south San Francisco Bay. Values are mean $\pm 1 \mathrm{SE}$. Asterisks indicate significant differences based on paired $t$-tests comparing invaded patches (Spartina hybrid) and uninvaded patches (tidal flat or Salicornia marsh). ${ }^{\star} 0.01 \leq \mathrm{p}<0.05, * \star 0.001 \leq \mathrm{p}<0.01$, $* * * \mathrm{p}<0.001$

ferences in below-ground structure between the Spartina hybrid-invaded habitat and open tidal flats (Fig. 6). At Elsie Roemer, hybrid-invaded sediments had a compact root matrix with no apparent lamination and bivalves and polychaete tubes were scarce (Fig. 6A). In contrast, the uninvaded tidal flat sediments were bioturbated, especially the top $2 \mathrm{~cm}$ layer, with visible tubes of spionid (e.g. Pygospio elegans, Streblospio benedicti) and capitellid polychaetes (Heteromastus filiformis, Capitella spp.) and bivalve shells (Gemma gemma) (Fig. 6B).

At Roberts Landing, the plant-invaded sediment had characteristics similar to Elsie Roemer, with a dense network of tiny rhizomes, 2 imperfect laminations (Fig. 6C) and the top few mm bioturbated by worm burrows. However, the adjacent tidal flat showed a conspicuously structured sediment profile (Fig. 6D). The uppermost $5 \mathrm{~cm}$ were relatively homogeneous with active feeding voids and
Redox potential
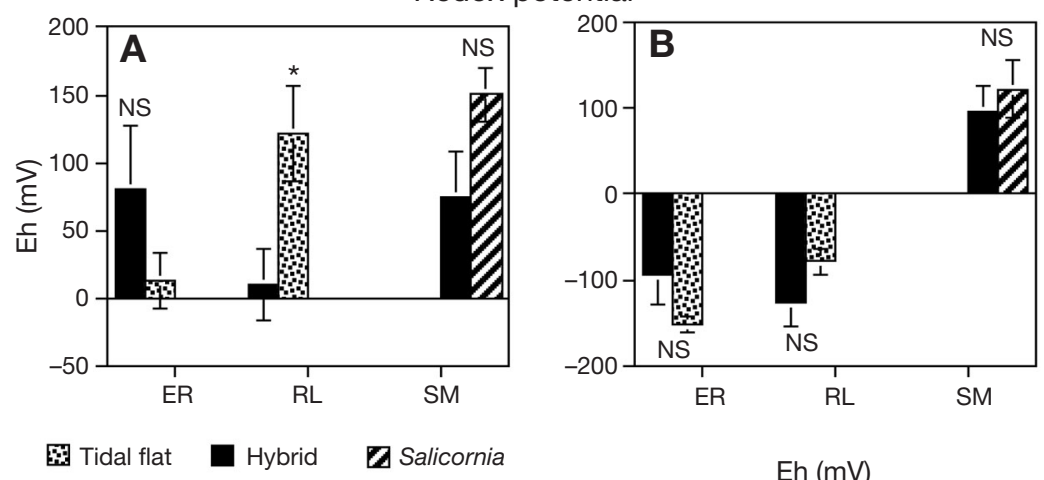

Fig. 5. Redox potential in sediments of Elsie Roemer (ER), Roberts Landing (RL) and San Mateo (SM) in south San Francisco Bay. (A) $1 \mathrm{~cm}$, (B) $5 \mathrm{~cm}$ sediment depth. Asterisks indicate significant differences based on paired $t$-tests comparing invaded patches (Spartina hybrid) and uninvaded patches (tidal flat or Salicornia marsh). *0.01 $\leq \mathrm{p}<0.05$. (C) Downcore profile from Elsie Roemer. Values are mean $\pm 1 \mathrm{SE}$

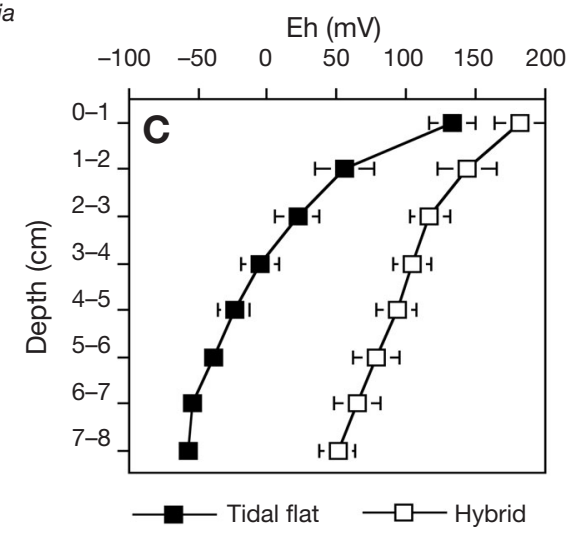



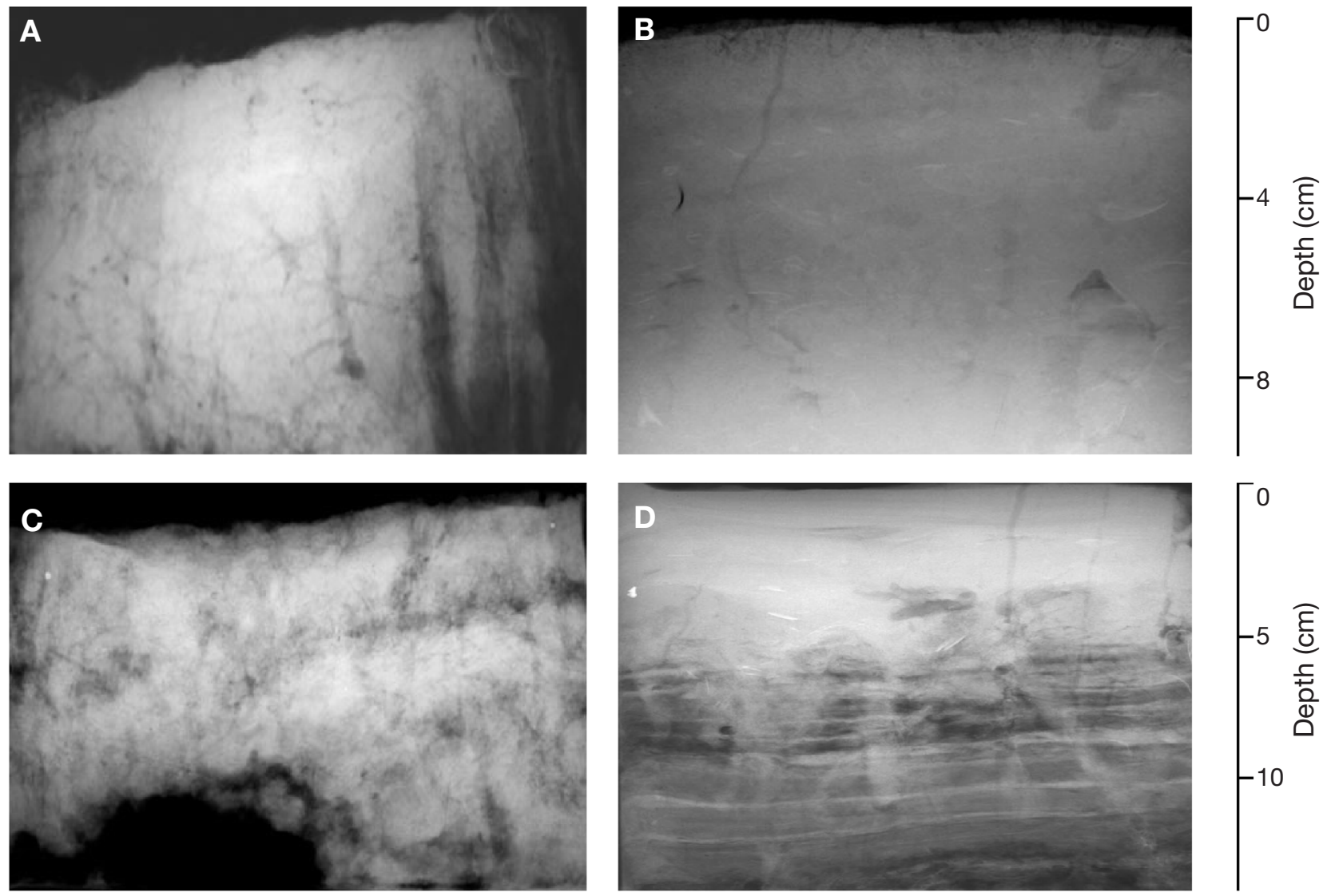

Fig. 6. X-radiographs of sediments from (A) Elsie Roemer hybrid Spartina marsh, (B) Elsie Roemer tidal flat, (C) Roberts Landing hybrid Spartina marsh, (D) Roberts Landing tidal flat. Note laminated sediments beneath a bioturbated zone in (D)

bivalve shells, with sediments crossed by capitellid burrows. Underneath this layer, the sediment displayed distinct laminae crossed by old roots and rhizomes, suggesting earlier vegetation at the site (Fig. 6D). The very thin lamination intervals indicated a rapid, short-term sediment accumulation in this formerly vegetated habitat. The presence of rooted vegetation disrupts the sediment layers and may have resulted in addition of organic material to greater depth.

\section{Macrofaunal abundance, composition and diversity}

Macrofaunal community structure differed in each system studied. At Elsie Roemer total density was $75 \%$ lower (p <0.001) in Spartina hybrid sediments (10.9 ind $\mathrm{cm}^{-2}$ ) than on tidal flats (41.3 ind. $\mathrm{cm}^{-2}$ ), but sediments of Roberts Landing and San Mateo exhibited no density differences between Spartina and reference sites (Fig. 7). Spartina hybrid areas were associated with lower species richness (evaluated as the number of species per core) and different macrofaunal community composition than the unvegetated tidal flat sites (Fig. 7). Significantly lower densities of amphipods (Grandidierella japonica, corophiid spp.), bivalves (Gemma gemma), and cirratulid polychaetes (Tharyx spp.) were recorded (Table 1). Densities of capitellid polychaetes (Heteromastus filiformis, Capitella spp.) and tubificid oligochaetes (Tubificoides brownae, $T$. fraseri) were similar in Spartina hybrid and tidal flat sediments (Table 1). No differences were recorded in faunal parameters or diversity indices between Spartina island and Spartina meadow sites at Elsie Roemer and Roberts Landing.

In the naturally vegetated marsh (San Mateo), Spartina hybrid- and Salicornia-dominated sediments exhibited few faunal differences (Fig. 7). Total macrofaunal densities were similar and only 5 of 32 species exhibited density differences in invaded and uninvaded patches. Two tubificid oligochaetes (Tubificoides brownae and Tubificoides sp. A) and a gastropod (Myosotella myosotis) were more abundant in hybrid-invaded sediments, while the tubificid oligochaete Tubificoides heterochaetus and 1 spionid polychaete (Pygospio elegans) were more abundant in Salicornia-vegetated sediments (Table 1). Species richness 

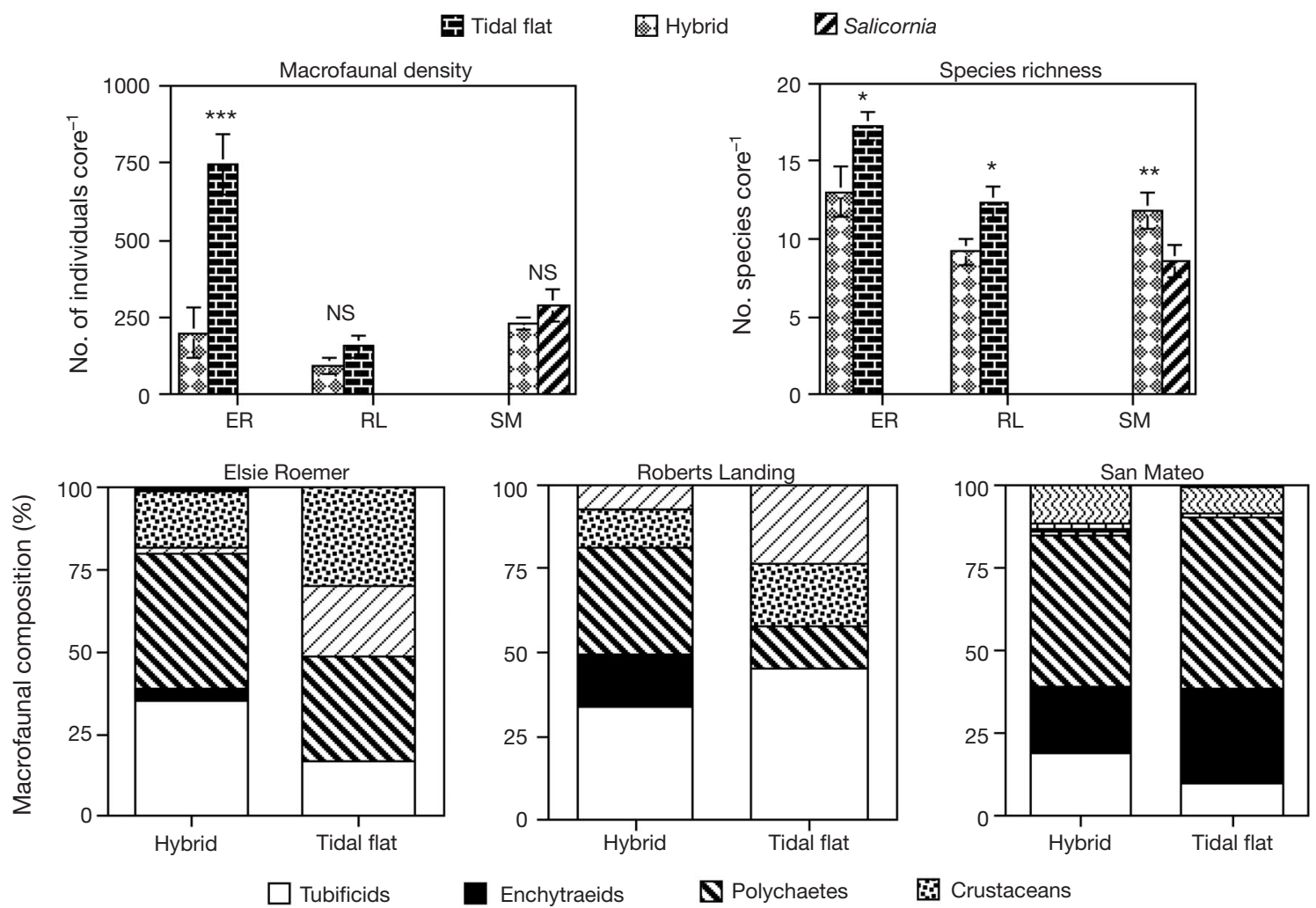

$\square$ Molluscs

四 Insects

B Others

Fig. 7. Macrofaunal density, species richness and composition at Elsie Roemer (ER), Roberts Landing (RL) and San Mateo (SM) in south San Francisco Bay. Values are mean \pm 1 SE. Asterisks indicate significant differences based on paired $t$-tests comparing invaded patches (Spartina hybrid) and uninvaded patches (tidal flat or Salicornia marsh). ${ }^{\star} 0.01 \leq \mathrm{p}<0.05, * \star 0.001 \leq \mathrm{p}<0.01, * * * \mathrm{p}<0.001$

was $30 \%$ higher $\left(t_{18}=2.7, \mathrm{p}=0.013\right)$ in the Spartina hybrid patches relative to the Salicornia meadow, which we attributed to the presence of podurid, ephidrid, aphidid, saldid, and formicid larval insect species. However, in terms of density there were no differences between habitats (Table 1).

Multivariate analyses (MDS) of macrofaunal assemblages (Fig. 8) indicate community differences between Spartina-invaded and uninvaded sediment (ANOSIM, $\mathrm{p}=0.001$ and $\mathrm{p}=0.003$, for Elsie Roemer and Roberts Landing, respectively). The extent of community similarity between Spartina-invaded and uninvaded habitats was similar in Elsie Roemer and in Roberts Landing (SIMPER, both $31 \%$ similarity, ANOSIM, p < 0.005) (Table 2). For our analysis we considered tall and short Spartina patches as a single entity in Roberts Landing because (1) they exhibited no difference in total macrofaunal density $\left(t_{8}=0.3, \mathrm{p}=\right.$ $0.805)$, (2) multivariate analyses indicated the macrofaunal assemblage was not different (ANOSIM, p = 0.754), and (3) densities of all 29 species present did not show significant differences (each $p>0.05$ ) between tall and short plant habitat. At San Mateo, macrofaunal communities in the Salicornia-vegetated (uninvaded) sediment differed from those patches invaded by Spartina hybrid (ANOSIM, $\mathrm{p}=0.014$ ), with only $50 \%$ similarity (SIMPER) (Fig. 8, Table 2).

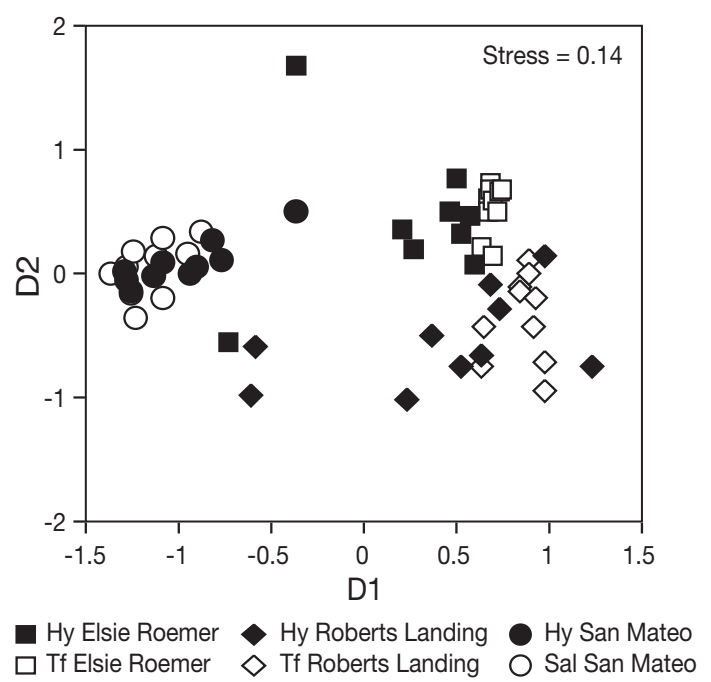

Fig. 8. Multidimensional scaling (MDS) plot of macrofaunal assemblages $(\leq 0.3 \mathrm{~mm})$ in hybrid-invaded sediments (Hy) and tidal flat sediments (Tf) at Elsie Roemer, Roberts Landing, and San Mateo in south San Francisco Bay 
Table 1. Mean densities of macrofauna $(>0.3 \mathrm{~mm}$ ) in Spartina hybrid-invaded and uninvaded tidal flats and Salicornia-dominated marshes of south San Francisco Bay. Values are average number of individuals per $18.1 \mathrm{~cm}^{2} \times 6 \mathrm{~cm}$ deep core $(1 \mathrm{SE})$, $\mathrm{n}=10$. Samples were collected in May/June 2001. p-values are given for paired $t$-tests comparing Spartina-invaded and uninvaded sediments at each site. 'Other Diptera' include Psychodidae larvae, Dolichopodidae pupae, Ceratopogonidae larvae, Ephidridae larvae

\begin{tabular}{|c|c|c|c|c|c|c|c|c|c|}
\hline \multirow{2}{*}{ Taxon } & \multicolumn{3}{|c|}{$\longrightarrow$ Elsie Roemer -} & \multicolumn{3}{|c|}{ Roberts Landing } & \multicolumn{3}{|c|}{ - San Mateo } \\
\hline & Spartina hybric & d Tidal flat & $\mathrm{p}$ & Spartina hybrid & Tidal flat & $\mathrm{p}$ & Spartina hybric & Salicornia & $\mathrm{p}$ \\
\hline \multirow{2}{*}{\multicolumn{10}{|c|}{ Annelida }} \\
\hline & \multicolumn{9}{|c|}{ Oligochaeta } \\
\hline Tubificoides brownae & $68.6(32.6)$ & $72.6(12.9)$ & 0.923 & $14.2(11.1)$ & $35.8(15.2)$ & 0.330 & $6.3(2.3)$ & 0 & 0.025 \\
\hline Tubificoides fraseri & $0.7(0.5)$ & $11.5(8.7)$ & 0.249 & $14.3(10)$ & $30.9(12.4)$ & 0.362 & $0.7(0.7)$ & 0 & 0.343 \\
\hline $\begin{array}{l}\text { Tubificoides hetero- } \\
\text { chaetus }\end{array}$ & 0 & 0 & & 0 & 0 & & $0.3(0.3)$ & $8(3)$ & 0.035 \\
\hline Tubificoides inops & 0 & 0 & & 0 & $1.9(1.3)$ & 0.198 & 0 & 0 & \\
\hline Tubificoides sp. A & 0 & 0 & & 0 & 0 & & $4.4(1.5)$ & $1.4(1.3)$ & 0.054 \\
\hline Tubificid sp. & 0 & 0 & & 0 & 0 & & $1.5(0.9)$ & $0.8(0.5)$ & 0.535 \\
\hline Tectidrilus diversus & 0 & $42(15.1)$ & 0.022 & 0 & 0 & & 0 & 0 & \\
\hline Limnodriloides barnardi & 0 & 0 & & $2.3(1.3)$ & $1.1(0.6)$ & 0.140 & 0 & 0 & \\
\hline $\begin{array}{l}\text { Monophylephorus } \\
\text { rubroniveus }\end{array}$ & 0 & 0 & & 0 & 0 & & $1.6(1)$ & 0 & 0.148 \\
\hline Naididae & 0 & 0 & & 0 & 0 & & $27.6(5.6)$ & $17(8.9)$ & 0.237 \\
\hline Enchytraeidae & $7.1(5.1)$ & 0 & 0.197 & $13.6(12.7)$ & 0 & 0.312 & $45.9(14)$ & $84.1(41)$ & 0.420 \\
\hline \multicolumn{10}{|l|}{ Polychaeta } \\
\hline $\begin{array}{l}\text { Pseudopolydora } \\
\text { paucibranchiata }\end{array}$ & 0 & $0.3(0.2)$ & 0.081 & 0 & 0 & & 0 & 0 & \\
\hline Pseudopolydora kempi & $3.9(2.8)$ & $8.1(8.1)$ & 0.221 & $0.3(0.3)$ & 0 & 0.193 & 0 & 0 & \\
\hline Polydora cornuta & $0.5(0.4)$ & $3.9(3.9)$ & 0.097 & $4.5(2.3)$ & $0.4(0.2)$ & 0.097 & 0 & 0.1 & 0.343 \\
\hline Boccardia proboscidea & $34.8(20.4)$ & $0.3(0.3)$ & 0.127 & 0 & 0 & & 0 & 0 & \\
\hline Streblospio benedicti & $9.5(8.4)$ & 34.1 (11.3) & 0.112 & $7.6(3.6)$ & $5.5(2.3)$ & 0.669 & $0.2(0.1)$ & $0.1(0.1)$ & 0.343 \\
\hline Pygospio elegans & $5(3.3)$ & 117 (45.8) & 0.034 & $1.2(0.7)$ & $0.5(0.3)$ & 0.321 & $4.8(3)$ & $17.5(5.8)$ & 0.037 \\
\hline Heteromastus filiformis & $5.5(2.2)$ & $3.5(0.7)$ & 0.400 & $3.4(1.5)$ & $1.5(0.2)$ & 0.269 & $2.8(1.3)$ & $35.2(21)$ & 0.147 \\
\hline Capitella spp. & $7.6(3.1)$ & $5.7(1.2)$ & 0.490 & 0 & 0 & & $0.7(0.7)$ & $0.5(0.5)$ & 0.829 \\
\hline Mediomastus sp. & 0 & 0 & & 0 & 0 & & $2.7(1.6)$ & $3(2.1)$ & 0.917 \\
\hline Eteone californica & $7.1(3.2)$ & $7.3(1.9)$ & 0.963 & $2.2(1.3)$ & $4.8(2.8)$ & 0.419 & $0.8(0.4)$ & $0.1(0.1)$ & 0.066 \\
\hline Eteone dilatae & $1.3(0.7)$ & $9(1.1)$ & $<0.0001$ & $3.3(1.3)$ & $7(2.4)$ & 0.052 & 0 & $0.1(0.1)$ & 0.343 \\
\hline $\begin{array}{l}\text { Sphaerosyllis } \\
\text { californiensis }\end{array}$ & $3.6(3.3)$ & $6.7(1.6)$ & 0.312 & 0 & 0 & & 0 & 0 & \\
\hline Fabricia limnicola & $0.4(0.4)$ & 0 & 0.343 & $3.2(3.2)$ & $0.1(0.1)$ & 0.359 & $91.4(15.6)$ & $94.3(23.9)$ & 0.903 \\
\hline Nereis succinea & $0.4(0.2)$ & $0.5(0.2)$ & 0.726 & $2.9(1)$ & $0.1(0.1)$ & 0.026 & $0.1(0.1)$ & $0.1(0.1)$ & 1.000 \\
\hline Tharyx sp. & $1.2(0.5)$ & 40.7 (11.3) & 0.007 & $0.1(0.1)$ & 0 & 0.343 & $2.4(2.4)$ & 0 & 0.343 \\
\hline Dorvillea sp. & $0.1(0.1)$ & 0 & 0.343 & 0 & 0 & & 0 & 0 & \\
\hline Goniadidae & 0 & $0.1(0.1)$ & 0.343 & 0 & 0 & & 0 & 0 & \\
\hline \multicolumn{10}{|l|}{ Mollusca } \\
\hline Musculista senhousia & $0.4(0.3)$ & 0 & 0.223 & 0 & 0 & & 0 & 0 & \\
\hline Myа sp. & $0.5(0.3)$ & $1.4(0.8)$ & 0.193 & $2(1.4)$ & $0.2(0.1)$ & 0.196 & 0 & 0 & \\
\hline Mya arenaria & 0 & 0 & & $0.1(0.1)$ & $0.2(0.1)$ & 0.591 & 0 & 0 & \\
\hline Tellina sp. & $0.1(0.1)$ & 0 & 0.343 & 0 & 0 & & 0 & 0 & \\
\hline Macoma petalum & 0 & 0 & & $3.4(1.8)$ & $6.8(2.3)$ & 0.346 & 0 & 0 & \\
\hline Gemma gemma & $0.5(0.3)$ & $159.543 .7)$ & 0.006 & $4.9(2.2)$ & $16.7(2.9)$ & 0.014 & 0 & 0 & \\
\hline Nutricola confusa & 0 & 0 & & 0 & $4.4(1.2)$ & 0.006 & 0 & 0 & \\
\hline Venerupis philippinarum & $1.6(0.5)$ & $1.5(0.6)$ & 0.899 & 0 & 0 & & 0 & 0 & \\
\hline \multicolumn{10}{|l|}{ Gastropoda } \\
\hline Myosotella myosotis & 0 & 0 & & 0 & 0 & & $1.6(0.4)$ & 0 & 0.004 \\
\hline \multicolumn{10}{|l|}{ Arthropoda } \\
\hline \multicolumn{10}{|l|}{ Peracarid crustacea } \\
\hline Corophiid spp. & $27.4(9.8)$ & $176.5(37.8)$ & 0.002 & $2.8(1.4)$ & $2.7(1.5)$ & 0.935 & $1.8(1.8)$ & $0.2(0.1)$ & 0.199 \\
\hline Grandidierella japonica & $5.2(3.5)$ & $36.9(13.1)$ & 0.048 & $2.3(1.5)$ & $14.5(9.8)$ & 0.251 & 0 & 0 & \\
\hline Hyale sp. & $0.5(0.4)$ & 0 & 0.244 & 0 & $2(1)$ & 0.073 & 0 & 0 & \\
\hline Gammarid sp. EE & 0 & 0 & & $1.2(1.2)$ & $15.9(11.7)$ & 0.196 & 0 & 0 & \\
\hline Gammarid sp. XX & 0 & 0 & & 0 & $0.8(0.5)$ & 0.136 & 0 & 0 & \\
\hline Amphitoe valida & $0.8(0.4)$ & $0.6(0.5)$ & 0.785 & 0 & 0 & & 0 & 0 & \\
\hline Orchestia traskiana & $0.2(0.1)$ & 0 & 0.168 & 0 & 0 & & $0.5(0.2)$ & $0.3(0.2)$ & 0.343 \\
\hline Ampeliscidae & 0 & 0 & & 0 & $0.1(0.1)$ & 0.343 & 0 & 0 & \\
\hline Caprellidae & $0.1(0.1)$ & 0 & 0.343 & 0 & 0 & & 0 & 0 & \\
\hline Exosphaeroma inornata & $0.2(0.1)$ & 0 & 0.168 & 0 & 0 & & 0 & 0 & \\
\hline Gnorimosphaeroma sp. & $0.1(0.1)$ & 0 & 0.43 & 0 & 0 & & 0 & 0 & \\
\hline Tanaidacea & $0.1(0.1)$ & $5.4(3.6)$ & 0.171 & 0 & 0 & & 0 & 0 & \\
\hline Cumacea & $0.1(0.1)$ & $0.4(0.2)$ & 0.279 & 0 & $0.4(0.2)$ & 0.036 & 0 & 0 & \\
\hline
\end{tabular}


Table 1 (continued)

\begin{tabular}{|c|c|c|c|c|c|c|c|c|c|}
\hline \multirow{2}{*}{ Taxon } & \multicolumn{3}{|c|}{ Elsie Roemer - } & \multicolumn{3}{|c|}{ Roberts Landing - } & \multicolumn{3}{|c|}{$\longrightarrow$ San Mateo $\longrightarrow$} \\
\hline & Spartina hybrid & Tidal flat & $\mathrm{p}$ & Spartina hybrid & Tidal flat & $\mathrm{p}$ & Spartina hybrid & Salicornia & $\mathrm{p}$ \\
\hline \multicolumn{10}{|l|}{ Insecta } \\
\hline \multicolumn{10}{|l|}{ Diptera } \\
\hline Poduridae & $0.8(0.7)$ & 0 & 0.280 & $0.2(0.1)$ & 0 & & $0.6(0.3)$ & 0 & \\
\hline Chironomidae larvae & 0 & 0 & & $0.2(0.2)$ & 0 & & 0 & 0 & \\
\hline Ormosia sp. (Tipulidae) & 0 & 0 & & 0 & 0 & & $3.3(1)$ & $1.8(0.9)$ & 0.329 \\
\hline 'Other Diptera' & 0 & 0 & & 0 & 0 & & $0.6(0.4)$ & $0.6(0.4)$ & 0.433 \\
\hline \multicolumn{10}{|l|}{ Homoptera } \\
\hline Aphidae & 0 & 0 & & 0 & 0 & & $0.1(0.1)$ & 0 & 0.343 \\
\hline \multicolumn{10}{|l|}{ Hemiptera } \\
\hline Saldidae & 0 & 0 & & 0 & 0 & & $0.1(0.1)$ & 0 & 0.343 \\
\hline \multicolumn{10}{|l|}{ Hymenoptera } \\
\hline Formicidae & 0 & 0 & & 0 & 0 & & $0.1(0.01)$ & 0 & \\
\hline \multicolumn{10}{|l|}{ Arachnida } \\
\hline Acari & $0.1(0.1)$ & 0 & 0.343 & 0 & 0 & & $0.5(0.3)$ & $1.2(1.1)$ & 0.568 \\
\hline \multicolumn{10}{|l|}{ Cnidaria } \\
\hline Hydrozoa & 0 & 0 & & 0 & 0 & & $26(7)$ & $23.1(8.2)$ & 0.797 \\
\hline \multicolumn{10}{|l|}{ Anthozoa } \\
\hline Nematostella vectensis & $0.3(0.2)$ & $0.5(0.3)$ & 0.443 & 0 & 0 & & 0 & 0 & \\
\hline \multicolumn{10}{|l|}{ Platyhelminthes } \\
\hline Turbellaria & $0.1(0.1)$ & $0.4(0.3)$ & 0.394 & 0 & 0 & & 0 & 0 & \\
\hline Nemertea & $0.3(0.3)$ & $0.3(0.3)$ & 1.000 & 0 & 0 & & 0 & 0 & \\
\hline No. ind. per core & $196.7(81.7)$ & 746.7 (99.2) & $<.001$ & $90.2(60.2)$ & $154.3(69.3)$ & 0.247 & $229.4(20.1)$ & $289.5(53.2)$ & 0.272 \\
\hline No. species per core & $13(4.1)$ & $17.2(0.9)$ & 0.018 & $9.2(0.9)$ & $12.3(1)$ & 0.049 & $11.8(1.2)$ & $8.6(1)$ & 0.008 \\
\hline
\end{tabular}

\section{Macrofaunal feeding modes}

Surface feeding was the most common feeding habit observed among wetland infauna in south San Francisco Bay (46 to $77 \%$ ). The second most common was subsurface-deposit feeding (19 to $49 \%$ ), followed by carnivory and omnivory ( 4 to $16 \%$ ) and herbivorous grazing $(0.3$ to $2 \%$ ). However, the proportional representation of each feeding mode varied between Spartina-invaded and uninvaded habitats. At Elsie Roemer, the proportion of surface feeders was higher in uninvaded tidal flat (77 $\pm 4 \%$ ) than in the hybrid-invaded habitat $(46 \% \pm 6 \%)\left(t_{18}=4.7\right.$, $\mathrm{p}=0.0002$ ). Conversely, the proportion of subsurfacedeposit feeders was significantly higher in the invaded habitat ( $t_{18}=3.9, \mathrm{p}=0.001$ ) (Fig. 9). At Roberts Landing there were no differences in feeding mode representation between Spartina-invaded and uninvaded tidal flat sediments. At San Mateo, no differences were detected in the representation of surface- $(\mathrm{p}=0.480)$ or in subsurface-deposit feeders $(\mathrm{p}=0.941)$ in Spartina-invaded versus Salicornia-dominated sediments. However, the proportion of carnivores/omnivores was 2.5 times higher $\left(t_{18}=4.7, \mathrm{p}=0.0002\right)$ and the proportion of grazers was 6.6 times higher $\left(t_{18}=3.3, \mathrm{p}=0.003\right)$ in the hybridinvaded patches relative to patches dominated by native Salicornia. Because the overall representation of carnivores and omnivores among infauna was very small in both patch types (Fig. 9), these trends may have minimal ecological significance.

\section{DISCUSSION}

Tidal flat invasion

The 3 benthic systems studied displayed variation in the type and magnitude of differences between Spartina-invaded sediments and native (uninvaded) patches. Contributing factors may include local properties which vary among locations, time since invasion, and the type of habitat being invaded. The Spartina invasion began much earlier at Elsie Roemer ( 30 yr) than at Roberts Landing (10 to $15 \mathrm{yr}$ ). In addition, elevations were lower ( $<1 \mathrm{~m}$ vs 2.5 to $2.8 \mathrm{~m}$ above MLLW), and the sediments were significantly coarser $\left(t_{18}=4.1, \mathrm{p}=\right.$ 0.0007) (Fig. 3) at Elsie Roemer than at Roberts Landing, indicating different flow regimes. The Spartina hybrid was taller at Elsie Roemer $\left(t_{18}=3.5, \mathrm{p}=0.0027\right)$, however, the below-ground biomass (upper $6 \mathrm{~cm}$ ) was higher in Roberts Landing $\left(t_{18}=3.0, \mathrm{p}=0.007\right)$. Among the 2 tidal flat invasions, we observed greater vegetation effects on sediment at Roberts Landing ( 7 of 9 properties, Figs. 4 \& 5), but much stronger effects on infaunal community structure at Elsie Roemer (Fig. 7, Table 1). These observations suggest that sediment properties are not driving the faunal differences alone. Rather, the faunal differences may be related to duration of Spartina influence, greater susceptibility of sandy faunas to plant influence on flow or detritus availability, or to variation in predation pressure. 
Table 2. Comparisons of macrofaunal assemblages of invaded and uninvaded habitats at 3 sites in San Francisco Bay sampled in May/June 2001. Probabilities resulting from pair-wise analysis of similarity (ANOSIM) tests for macrofaunal similarities between habitats are given above the diagonal. Values on the diagonal are percent similarity within habitat (SIMPER); values below the diagonal are percent dissimilarity between habitat (SIMPER). Significance was set at $\alpha=0.05 . \mathrm{H}$ ER $=$ Spartina hybrid Elsie Roemer, H RL = Spartina hybrid Roberts Landing, H SM = Spartina hybrid San Mateo, T ER = tidal flat Elsie Roemer, $\mathrm{T}$ RL $=$ tidal flat Roberts Landing, $\mathrm{S}$ SM $=$ Salicornia San Mateo

\begin{tabular}{|lcccccc|}
\hline $\begin{array}{l}\text { SITE/ } \\
\text { HABITAT }\end{array}$ & H ER & H RL & H SM & T ER & T RL & S SM \\
\hline H ER & $32.29 \%$ & 0.002 & 0.001 & 0.001 & 0.001 & 0.001 \\
H RL & $78.57 \%$ & $28.73 \%$ & 0.001 & 0.001 & 0.003 & 0.001 \\
H SM & $85.51 \%$ & $88.27 \%$ & $57.84 \%$ & 0.001 & 0.001 & 0.014 \\
T ER & $68.63 \%$ & $77.89 \%$ & $90.37 \%$ & $62.94 \%$ & 0.001 & 0.001 \\
T RL & $79.51 \%$ & $68.86 \%$ & $91.83 \%$ & $71.66 \%$ & $47.03 \%$ & 0.001 \\
S SM & $88.85 \%$ & $89.39 \%$ & $49.82 \%$ & $92.55 \%$ & $95.72 \% 51.11 \%$ \\
\hline
\end{tabular}

The low elevation and high-energy regime of Elsie Roemer in June 2001 are associated with exceptionally high faunal densities on the tidal flat $(\approx 400000$ ind. $\mathrm{m}^{-2}$ ). Of the individuals present, $80 \%$ belong to 2 taxa (Gemma gemma and corophiid amphipod species; Table 1), so much of the apparent invasion effect at Elsie Roemer (75\% lower density in Spartina patches) may be attributed to declines in these surface-feeding taxa (Fig. 9). This pattern is persistent over seasons and years; total macrofaunal densities were $71 \%$ lower in the invaded areas than in tidal flats (E. Brusati pers. comm.) in October 2001 and 64\% lower in July 2003 (C.N. pers. obs.).

Some responses of the Roberts Landing and Elsie Roemer tidal flat ecosystem to Spartina invasion were similar. At both sites about half of the species present (51 and 55\%) exhibited lower mean densities in the Spartina-invaded sediments (Table 1). Furthermore, both locations exhibited a $25 \%$ decline in macroinfaunal species richness (Fig. 7).

Our findings of lower density and species richness in tidal flats habitats invaded by Spartina hybrid contrast sharply with existing paradigms about positive vegetation effects on marine macrobenthos (Bertness et al. 2000). However, a survey of the literature addressing Spartina influence on macrobenthos reveals disparate patterns, depending on the Spartina species, habitats and geographic region involved (Table 3). Where $S$. alterniflora is a native (West Atlantic) and mature (natural marshes), it appears to enhance macrofaunal density and species richness relative to mudflats. Presence of vegetation may enhance infaunal densities via increased substrate stability, increased food resources, refuge from predators, and hence greater survivorship (Orth 1977, Orth et al. 1991, Lee \& Kneib 1994). Newly planted Spartina has little effect on macrobenthos however (Levin et al. 1996, Craft \& Sacco 2003).

On the Pacific coast, where Spartina is invasive ( $S$. anglica, Spartina hybrid) or the native is $S$. foliosa, Spartina-inhabited sediments seemed to have lower macroinfaunal densities relative to the mudflat (present study, Table 3). Our observation of reduced den-
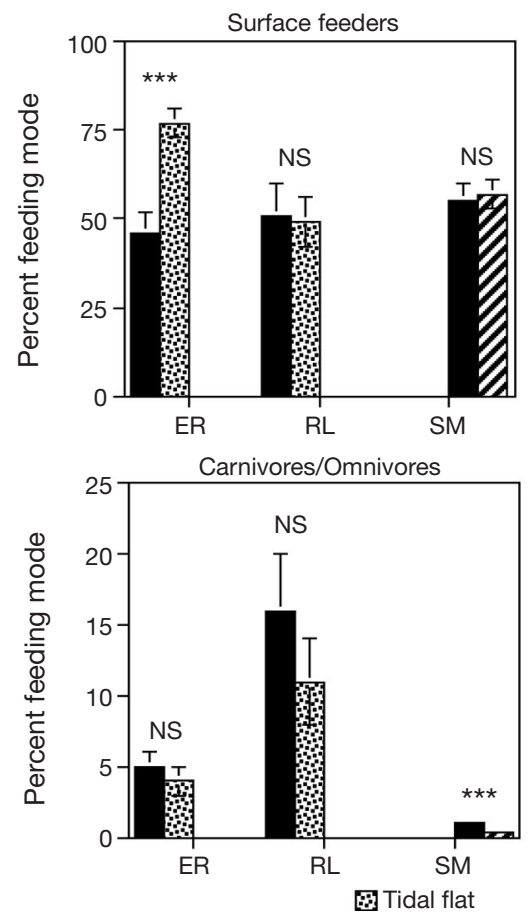
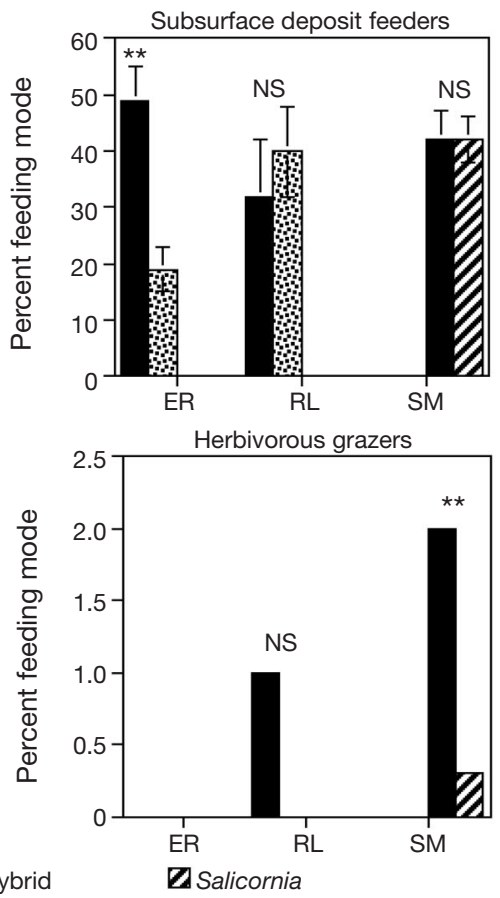

Fig. 9. Mean percent representation of macrofaunal feeding groups within the hybrid-invaded and uninvaded habitats of Elsie Roemer, Roberts Landing and San Mateo during May/June 2001. Data are based on 10 cores from each habitat. ${ }^{* *}=0.001 \leq \mathrm{p}<0.01$, $\star * *=\mathrm{p}<0.001$ 
Table 3. Spartina spp. Influence on benthic macrofaunal populations and communities

\begin{tabular}{|c|c|c|c|}
\hline $\begin{array}{l}\text { Vegetation type/ } \\
\text { location }\end{array}$ & $\begin{array}{l}\text { Taxon } \\
\text { studied }\end{array}$ & Influence on fauna & Source \\
\hline $\begin{array}{l}\text { S. alterniflora } \\
\text { Galveston Bay, Texas, USA }\end{array}$ & $\begin{array}{l}\text { Macrofauna/ } \\
\text { meiofauna }\end{array}$ & $\begin{array}{l}\text { Higher mean densities of most macroafaunal and meiofaunal species } \\
\text { in vegetated sediments than in unvegetated areas }\end{array}$ & Wardle et al. (2001) \\
\hline $\begin{array}{l}\text { S. alterniflora } \\
\text { Paranaguá Bay, Paraná, Brazil }\end{array}$ & Macrofauna & $\begin{array}{l}\text { Higher density, species richness, and greater temporal stability in } \\
\text { vegetated areas compared with unvegetated areas }\end{array}$ & Lana \& Guiss (1991) \\
\hline $\begin{array}{l}\text { S. alterniflora } \\
\text { Tar Landing Bay, } \\
\text { North Carolina, USA }\end{array}$ & $\begin{array}{l}\text { Macrofauna/ } \\
\text { meiofauna }\end{array}$ & $\begin{array}{l}\text { Higher macrofauna and meiofauna densities in sediments containing } \\
\text { S. alterniflora culms than in unvegetated sediments }\end{array}$ & Rader (1984) \\
\hline $\begin{array}{l}\text { S. alterniflora } \\
\text { Galveston Bay, Texas, USA }\end{array}$ & $\begin{array}{l}\text { Peracarid } \\
\text { crustaceans }\end{array}$ & $\begin{array}{l}\text { Higher peracarid density in sediments containing S. alterniflora } \\
\text { stems than in bare sediments }\end{array}$ & Goldberg (1996) \\
\hline $\begin{array}{l}\text { S. alterniflora } \\
\text { Paranaguá Bay, Paraná, Brazil }\end{array}$ & Gastropods & $\begin{array}{l}\text { Higher densities of Neritina virginea with increased Spartina density, } \\
\text { biomass and height }\end{array}$ & Bonnet et al. (1994) \\
\hline $\begin{array}{l}\text { S. alterniflora } \\
\text { Alabama, USA }\end{array}$ & Clams & $\begin{array}{l}\text { Positive correlation between stem density and Geukensia demissa } \\
\text { density }\end{array}$ & $\begin{array}{l}\text { West \& Williams } \\
\text { (1986) }\end{array}$ \\
\hline $\begin{array}{l}\text { S. alterniflora } \\
\text { Galveston Bay, Texas, USA }\end{array}$ & $\begin{array}{l}\text { Natant } \\
\text { macrofauna }\end{array}$ & $\begin{array}{l}\text { Palaemonetes pugio, Penaeus aztecus and Callinectes sapidus } \\
\text { more abundant in vegetated than in unvegetated patches }\end{array}$ & $\begin{array}{l}\text { Zimmerman \& } \\
\text { Minello (1984) }\end{array}$ \\
\hline $\begin{array}{l}\text { S. alterniflora } \\
\text { Galveston Bay, Texas, USA }\end{array}$ & $\begin{array}{l}\text { Natant } \\
\text { macrofauna }\end{array}$ & $\begin{array}{l}\text { Macrobenthic, juvenile blue crabs and fiddler crab diversity unaffected } \\
\text { by unvegetated channel presence. Oligochaetes present mostly in } \\
\text { vegetated patches }\end{array}$ & $\begin{array}{l}\text { Minello et al. } \\
\text { (1994) }\end{array}$ \\
\hline $\begin{array}{l}\text { S. alterniflora } \\
\text { Willapa Bay, Washington } \\
\text { State, USA }\end{array}$ & Macrofauna & $\begin{array}{l}\text { Higher densities in invaded patches in April and lower densities in } \\
\text { August relative to open tidal flat. Increased densities of } \\
\text { subsurface-deposit feeders in invaded patches }\end{array}$ & Zipperer (1996) \\
\hline $\begin{array}{l}\text { S. alterniflora } \\
\text { Willapa Bay, Washington } \\
\text { State, USA }\end{array}$ & Clams & $\begin{array}{l}\text { Lower Macoma inconspicua density in } S \text {. alterniflora patches than in } \\
\text { mudflats. Mya arenaria varied from greatest densities along the inside } \\
\text { edge of the patches in spring, to higher densities on the mudflat in summer }\end{array}$ & Ratchford (1995) \\
\hline $\begin{array}{l}\text { S. alterniflora } \\
\text { Willapa Bay, Washington } \\
\text { State, USA }\end{array}$ & Clams & $\begin{array}{l}\text { Lower densities of Macoma spp. and higher densities of Venerupis } \\
\text { philipinarum in Spartina patches than in mudflats }\end{array}$ & $\begin{array}{l}\text { Dumbauld et al. } \\
(1997)\end{array}$ \\
\hline $\begin{array}{l}\text { S. alterniflora } \\
\text { Willapa Bay, Washington } \\
\text { State, USA }\end{array}$ & Macrofauna & $\begin{array}{l}\text { Lower densities of crustaceans and bivalves, enhanced densities of } \\
\text { dipteran in } S \text {. alterniflora-invaded mudflats }\end{array}$ & O'Connell (2002) \\
\hline $\begin{array}{l}\text { S. alterniflora } \\
\text { North Carolina, Louisiana, USA }\end{array}$ & Macrofauna & Lower diversity in salt marshes relative to adjacent mudflats & Cammen (1979) \\
\hline $\begin{array}{l}\text { S. alterniflora, S. cynosuroides, } \\
\text { Juncus roemerianus } \\
\text { Cape Fear Estuary, NC, USA }\end{array}$ & Clams & Lower densities in Spartina than in J. roemerianus marsh & $\begin{array}{l}\text { Capehart \& } \\
\text { Hackney (1989) }\end{array}$ \\
\hline $\begin{array}{l}\text { S. alterniflora and created marsh } \\
\text { Galveston Bay, Texas, USA }\end{array}$ & Macrofauna & $\begin{array}{l}\text { Higher densities and species richness (mainly polychaetes) in natural } \\
\text { S. alterniflora patches than in created, vegetated marsh }\end{array}$ & $\begin{array}{l}\text { Minello \& Webb } \\
(1997)\end{array}$ \\
\hline $\begin{array}{l}\text { S. alterniflora and } \\
\text { Schoenoplectus robustus } \\
\text { North Carolina, USA }\end{array}$ & Macrofauna & $\begin{array}{l}\text { Higher abundances in older-vegetated than in young-vegetated sites. } \\
\text { Macrofauna composition differed between the oldest (15 yr) and } \\
\text { youngest ( } 4 \text { yr) sites }\end{array}$ & Posey et al. (1997) \\
\hline $\begin{array}{l}\text { S. alterniflora } \\
\text { North Carolina, USA }\end{array}$ & Macrofauna & $\begin{array}{l}\text { No differences in successsion of vegetated versus unvegetated plots in } \\
\text { a created marsh }\end{array}$ & Levin et al. (1996) \\
\hline $\begin{array}{l}\text { S. anglica and native marsh } \\
\text { Little Swanport, Tasmania, } \\
\text { Australia }\end{array}$ & Macrofauna & $\begin{array}{l}\text { Higher species richness and higher total abundance of invetebrates in } \\
\text { S. anglica marsh and native salt marsh relative to mudflat }\end{array}$ & $\begin{array}{l}\text { Hedge \& } \\
\text { Kriwoken (2000) }\end{array}$ \\
\hline $\begin{array}{l}\text { S. anglica, Salicornia spp. } \\
\text { Norfolk, England }\end{array}$ & Macrofauna & Lower species richness in vegetated areas than in sand and mudflat & $\begin{array}{l}\text { Frid \& James } \\
(1989)\end{array}$ \\
\hline $\begin{array}{l}\text { S. anglica } \\
\text { Seafield Bay, Suffolk, England }\end{array}$ & Macrofauna & $\begin{array}{l}\text { Lower densities of bivalves and Corophium, and higher densities of } \\
\text { tubificid oligochaetes in vegetated areas relative to mudflat }\end{array}$ & Jackson (1985) \\
\hline $\begin{array}{l}\text { S. foliosa } \\
\text { Mission Bay, California, USA }\end{array}$ & Macrofauna & Lower density and species richness on salt marsh than mudflat & Levin et al. (1998) \\
\hline $\begin{array}{l}\text { S. foliosa, Salicornia virginica } \\
\text { and S. bigelovii } \\
\text { Mission and San Diego Bays, } \\
\text { California, USA }\end{array}$ & Macrofauna & $\begin{array}{l}\text { Higher tubificid oligochaete densities in S. foliosa, higher insect, } \\
\text { naidid oligochaete and peracarid densities in Salicornia }\end{array}$ & $\begin{array}{l}\text { Talley \& Levin (1999) } \\
\text { Levin \& Talley ( 2000) }\end{array}$ \\
\hline $\begin{array}{l}\text { S. foliosa, Salicornia bigelovii } \\
\text { Tijuana Estuary, California, USA }\end{array}$ & Macrofauna & $\begin{array}{l}\text { Higher density of polychaetes and insects in Spartina foliosa, higher } \\
\text { density of gastropods, naidid and enchytraeid oligochaetes and pera- } \\
\text { carids in S. virginica }\end{array}$ & Levin et al. (1997) \\
\hline $\begin{array}{l}\text { Spartina hybrid invading } \\
\text { tidal flat } \\
\text { San Francisco Bay, USA }\end{array}$ & Macrofauna & $\begin{array}{l}\text { Lower total density and species richness in Spartina hybrid-invaded } \\
\text { areas than in tidal flats. Loss of surface feeders; increases or no effect } \\
\text { on subsurface-deposit feeders in vegetated patches }\end{array}$ & This study \\
\hline $\begin{array}{l}\text { Spartina hybrid invading } \\
\text { Salicornia marsh } \\
\text { San Francisco Bay, USA }\end{array}$ & Macrofauna & $\begin{array}{l}\text { Slight difference in faunal composition with higher species richness in } \\
\text { hybrid-invaded patches relative to Salicornia marsh, but no differences } \\
\text { in total densities }\end{array}$ & This study \\
\hline
\end{tabular}


sities of surface-feeding animals (corophiids and bivalves) concur with those reported for invasive $S$. anglica (Jackson 1985), and S. alterniflora (Zipperer 1996) (Table 3). In Willapa Bay S. alterniflora invasion of tidal flats led to lower abundances of crustaceans and bivalves as well as burrowing polychaetes, and enhanced densities of dipteran larva and pupae (O'Connell 2002). We did not find these trends in polychaetes and insects in the tidal invasions of south San Francisco Bay, although insect species richness was greater in Spartina patches relative to Salicornia patches in the San Mateo marsh.

\section{Salt marsh invasion}

A nearly opposite benthic response to that reported at Elsie Roemer and Roberts Landing was observed in the marsh invasion at San Mateo, where the native habitat is dominated by Salicornia virginica. Total faunal densities did not differ between Spartina hybrid and Salicornia patches, but more individuals were collected in Spartina patches for $72 \%$ of the species, and species richness per core was $27 \%$ greater in the Spartina-invaded sediments. Not only was this site vegetated prior to the invasion, but the sediments were more saline $\left(F_{2,27}=3.25, \mathrm{p}=0.05\right)$, finer-grained $\left(F_{2,27}=\right.$ $65.8, \mathrm{p}<0.0001)$, more porous $\left(F_{2,27}=57.5, \mathrm{p}<0.0001\right)$ and had higher organic content $\left(F_{2,27}=216.5, \mathrm{p}<0.0001\right)$ and microalgal biomass $\left(F_{2,27}=27.8, \mathrm{p}<0.0001\right)$ than the other sites (Fig. 4). The invaded sediments of San Mateo also exhibited higher concentrations of the algal pigments fucoxanthin $\left(F_{2,27}=4.772, \mathrm{p}=0.017\right)$, zeaxanthin $\left(F_{3,36}=4.009, \mathrm{p}=0.014\right)$, and lutein $\left(F_{3,33}=\right.$ $6.223, \mathrm{p}=0.002)$ than the Spartina-invaded tidal flats of Elsie Roemer and Roberts Landing.

There are few consistent, general trends evident in comparisons of macrobenthos inhabiting Spartina versus other forms of marsh vegetation (Table 3). Lower bivalve densities have been noted in Spartina-vegetated sediments relative to Juncus roemerianus (Capehart \& Hackney 1989). In the Tijuana estuary, southern California, there were higher densities of polychaetes and insects in $S$. foliosa habitats, while in $S$. virginica habitats, gastropods, naidid and enchytraeid oligochaetes dominated in density (Levin et al. 1997). In nearby Mission Bay, the Spartina zone had higher densities of tubificid oligochaetes and lower densities of insects, peracarid crustaceans and naidid oligochaetes than the Salicornia zone (Talley \& Levin 1999, Levin \& Talley 2000). At San Mateo we observed higher species richness and increased densities of several tubificid species and a gastropod, as well as greater insect richness in the Spartina-invaded than Salicornia habitat (Table 1). As the invaded habitat is transformed into a monospecific Spartina hybrid stand, the sediments at San Mateo become less densely vegetated, possibly facilitating some macrobenthic species showing enhancement (Table 1).

\section{Mechanisms of change, trophic implications and possible consequences}

Across the range of locations and habitats studied, we observed varied macrofaunal responses to Spartina invasion, ranging from density reduction (Elsie Roemer), to composition change (Roberts Landing), to species enhancements (insects - San Mateo). A full mechanistic understanding of the sources of this variation would entail detailed, experimental studies of Spartina hybrid effects on flow, substrate, elevation, light, algal production, predation pressure, and other possible factors. Successional studies that track changes in single invasions over time, at a number of different sites with different substrata and in different vegetation regimes, will help distinguish the relative importance of invasion duration from various environmental factors.

Many of the species shown to have lowered density in tidal flat habitats invaded by hybrid Spartina are surface-feeding forms such as Gemma gemma, Corophium spp., Grandidierella japonica, Tharyx spp., Streblospio benedicti, and Pygospio elegans. These are more readily consumed by predatory fish and birds (Green \& Hobson 1970, Whitlatch 1977, Thompson 1982, Nichols \& Thompson 1985a,b) than invasion-tolerant, subsurface-deposit feeders such as capitellid polychaetes and oligochaetes that live deeper in the sediment column and are less accessible to epibenthic predators. Thus, where Spartina has invaded open tidal flat for several decades, the foraging area and food base for shorebirds and epibenthic fish has probably declined. In contrast, Spartina invasion of Salicornia marsh could provide a more rich and diverse food base for other kinds of wetland consumers. In both types of invasion, Spartina has created additional habitat for the endangered California clapper rail in south San Francisco Bay (J. C. Nordby pers. comm.), adding complexity to already difficult decision-making concerning control measures. The present studies illustrate the heterogeneous, contextdependent effects of an invasive plant on benthos in tidal wetlands. They also suggest, but do not confirm, time dependence.

Acknowledgements. We thank the many people who have assisted with the field collections and infaunal sorting, especially Rachel Blake, Philip Colombano, Jennifer Gonzalez, Guillermo Mendoza, Renate Neira, Steve Norton, Nicki Rayl, Missy Soto, Christine Whitcraft and Maria Young. We are 
grateful to Pablo Rosso, who kindly provided aerial color IR photographs and maps, and G. Mendoza, who assisted with map preparation. We thank Pat McMillan for assistance in the lab. We deeply acknowledge Chris Janousek for his assistance with HPLC. Also we thank Jessica Nolan, Ralf Goerike and Maria Vernet for providing facilities and materials for pigment analyses. Two anonymous reviewers provided valuable comments on an earlier version of this manuscript. Grant support was provided by the National Science Foundation Biocomplexity Program (DEB 0083583).

\section{LITERATURE CITED}

Adam P (2002) Salt marshes in a time of change. Environ Conserv 29:39-61

Anderson CE (1974) A review of structure in several North Carolina salt marsh plants. In: Reimold RJ, Queen VH (eds) Ecology of halophytes. Academic Press, New York, p 307-344

Ayres DR, Garcia-Rossi D, Davis HG, Strong DR (1999) Extent and degree of hybridization between exotic (Spartina alterniflora) and native ( $S$. foliosa) cordgrass (Poaceae) in California, USA determined by random amplified polymorphic DNA (RAPDSs). Mol Ecol 8:1179-1186

Ayres DR, Strong DR, Baye P (2003) Spartina foliosa (Poaceae) - a common species on the road to rarity. Madroño 50: 209-213

Ayres DR, Smith DL, Zaremba K, Klohr S, Strong DR (2004) Spread of exotic cordgrasses and hybrids (Spartina sp.) in the tidal marshes of San Francisco Bay. Biol Invasions 6:221-231

Bertness MD (1988) Peat accumulation and success of marsh plants. Ecology 69:703-713

Bertness MD, Gaines SD, Hay ME (2000) Marine community ecology. Sinauer Associates, Sunderland, MA

Bonnet BRP, Lana PC, Guiss C (1994) Influência de gramínea Spartina alterniflora sobre a distribuiçào e densidade de Neritina virginea (Gastropoda: Neritidae) em Marismas da Baia de Paranaguá (Paraná, Brasil). Neritica Curitiba 8:99-108

Brotas V, Plante-Cuny MR (1998) Spatial and temporal patterns of microphytobenthic taxa of estuarine tidal flats in the Tagus Estuary (Portugal) using pigment analysis by HPLC. Mar Ecol Prog Ser 171:43-57

Buchanan JB (1984) Sediment analysis. In: Holme NA, McIntyre AD (eds) Methods for the study of marine benthos, 2nd edn. Blackwell Scientific, London, p 41-65

Callaway JC, Josselyn MN (1992) The introduction and spread of smooth cordgrass (Spartina alterniflora) in South San Francisco Bay. Estuaries 15:218-226

Cammen LM (1979) The macro-infauna of a North Carolina salt marsh. Am Midland Naturalist 102:244-253

Capehart AA, Hackney C (1989) The potential role of roots and rhizomes in structuring salt marsh benthic communities. Estuaries 12:119-122

Chung C (1990) Twenty-five years of introduced Spartina anglica in China. In: Gray AJ, Benham PEM (eds) Spartina anglica: a research review. Research publication No. 2. Institute of Terrrestrial Ecology, London, p 72-76

Clarke KR (1993) Non-parametric multivariate analyses of changes in community structure. Aust J Ecol 18:117-143

Clarke KR, Warwick RM (1994) Change in marine communities: an approach to statistical analysis and interpretation. Natural Environmental Research Council and Plymouth Marine Laboratory, Plymouth

Craft C, Sacco J (2003) Long-term succession of benthic infauna communities on constructed Spartina alterniflora marshes. Mar Ecol Prog Ser 257:45-58

Crooks JA (2002). Characterizing ecosystem-level consequences of biological invasions: the role of ecosystem engineers. Oikos 97:153-166

Currin CA, Newell SY, Pearl HW (1995) The role of standing dead Spartina alterniflora and benthic microalgae in salt marsh food webs: considerations based on multiple stable isotope analysis. Mar Ecol Prog Ser 121:99-116

Daehler CC, Strong DR (1996) Status, prediction and prevention of introduced cordgrass Spartina spp. invasions in Pacific estuaries, USA. Biol Conserv 78:51-58

Daehler CC, Strong DR (1997) Hybridization between introduced smooth cordgrass (Spartina alterniflora, Poaceae) and native California cordgrass (Spartina foliosa) in San Francisco Bay, California, USA. Am J Bot 85:607-611

De la Cruz A, Hackney CT, Bhardwaj N (1989) Temporal and spatial patterns of redox potential (Eh) in three tidalmarsh communities. Wetlands 9:181-190

Dumbauld BR, Peoples M, Holcomb L, Ratchford S (1997) The potential influence of the aquatic weed Spartina alterniflora and control practices on clam resources in Willapa Bay, Washington. In: Patten K (ed) Proc 2nd Int Spartina Conf, Washington State University, Olympia, WA, p 51-57

Fauchald K, Jumars P (1979) The diet of worms: a study of polychaete feeding guilds. Oceanogr Mar Biol 17:193-284

Frid C, James R (1989) The marine invertebrate fauna of a British coastal salt marsh. Hol Ecol 12:9-15

Gambrell RP, Patrick WH (1978) Chemical and microbiological properties of anaerobic soils and sediments. In: Hook DD, Crawford RMM (eds) Plant life in anaerobic environments. Ann Arbor Scientific, Ann Arbor, MI, p 375-423

Giere O, Eleftheriou A, Murison DJ (1988) Abiotic factors. In: Higgins RP, Thiel $\mathrm{H}$ (eds) Introduction to the study of meiofauna, Smithsonian Institution Press, Washington, DC, p 61-78

Goldberg AR (1996) Development of infaunal populations and below-ground organic matter from three created Spartina alterniflora marshes in Galveston Bay, Texas. MS thesis, Texas A\&M University, College Station, TX

Green RH, Hobson KD (1970) Spatial and temporal structure in a temperate intertidal community, with special emphasis on Gemma gemma (Pelecypoda: Mollusca). Ecology 51:999-1011

Hedge P, Kriwoken LK (2000) Evidence for effects of Spartina anglica invasion on benthic macrofauna in Little Swanport estuary, Tasmania. Aust Ecol 25:150-159

Jackson D (1985) Invertebrate populations associated with Spartina anglica salt-marsh and adjacent intertidal mud flats. Estuar Brackishw Sci Assoc Bull 40:8-14

Jones CG, Lawton JH, Shachak M (1994) Organisms as ecosystem engineering. Oikos 689:373-386

Kreeger DA, Newell IE (2000) Trophic complexity between producers and invertebrates consumers in salt marshes. In: Weinstein M, Kreeger DA (eds) Concepts and controversies in tidal marsh ecology. Kluwer Academic Publishers, Dordrecht, p 187-220

Lana PC, Guiss C (1991) Influence of Spartina alterniflora on structure and temporal variability of macrobenthic associations in a tidal flat of Paranaguá Bay (southeastern Brazil). Mar Ecol Prog Ser 73:231-244

Lee SY, Kneib RT (1994) Effects of biogenic structure on prey consumption by the xanthid crabs Eurytium limosum and Panopeus herbstii in a salt marsh. Mar Ecol Prog Ser 104: 39-47

Leonard LA, Luther ME (1995) Flow dynamics in tidal marsh canopies. Limnol Oceanogr 40:1474-1484 
Leonard LA, Wren PA, Beavers RL (2002) Flow dynamics and sedimentation in Spartina alterniflora and Phragmites australis marshes of the Chesapeake Bay. Wetlands 22:415-424

Levin LA, Talley TS (2000) Influences of vegetation and abiotic environmental factors on salt marsh benthos. In: Weinstein MP, Kreeger DA (eds) Concepts and controversies in tidal marsh ecology. Kluwer Academic, Amsterdam, p 661-708

Levin LA, Talley DM, Thayer G (1996) Macrobenthic succession in a created salt marsh. Mar Ecol Prog Ser 141:67-82

Levin LA, Talley TS, Larson AA, Jones A (1997) Faunal composition in the Tijuana River estuarine intertidal habitats and the role of life histories in faunal recovery of southern California restored wetlands. Final report for the National Estuarine Research Reserve System, NOAA Award No. NA 670R0237, August 1997

Levin LA, Talley TS, Hewitt J (1998) Macrobenthos of Spartina foliosa (Pacific Cordgrass) salt marshes in southern California: community structure and comparison to a Pacific mudflat and a Spartina alterniflora (Atlantic Smooth Cordgrass) marsh. Estuaries 21:120-144

Meyer-Reil LA (1983) Benthic response to sedimentation events during autumn to spring at a shallow water station in the Western Kiel Bight. II. Analysis of benthic bacterial populations. Mar Biol 77:247-256

Minello TJ, Webb JW (1997) Use of natural and created Spartina alterniflora salt marshes by fishery species and other aquatic fauna in Galveston Bay, Texas, USA. Mar Ecol Prog Ser 151:165-179

Minello TJ, Zimmerman RJ, Medina R (1994) The importance of edge for natant macrofauna in a created salt marsh. Wetlands 14:184-198

Nichols FH, Thompson JK (1985a) Persistence of an introduced mudflat community in South San Francisco Bay, California. Mar Ecol Prog Ser 24:83-97

Nichols FH, Thompson JK (1985b) Time scales of change in the San Francisco Bay benthos. Hydrobiol 129:121-138

O'Connell KA (2002) Effects of invasive Atlantic smooth-cordgrass (Spartina alterniflora) on infaunal macroinvertevrate communities in southern Willapa Bay, WA. MS thesis, Western Washington University, Bellingham, WA

Orth RJ (1977) The importance of sediment stability in seagrass communities. In: Coull B (ed) Ecology of marine benthos. University of South Carolina Press, Columbia, $\mathrm{SC}, \mathrm{p} 281-300$

Orth RJ, Heck KL, Diaz RJ (1991) Littoral and intertidal systems in the mid-Atlantic coast of the United States. In: Mathieson AC, Nienhuis PH (eds) Intertidal and littoral ecosystems. Elsevier, Amsterdam, p 193-209

Pinckney J, Paerl H, Fitzpatrick M (1995) Impacts of seasonality and nutrients on microbial mat community structure and function. Mar Ecol Prog Ser 123:207-216

Plante-Cuny MR (1973) Reserches sur la production primaire bentique en milieu marin tropical. I. Variations de la production primaire et des teneurs en pigments photosynthétiques sur quelques fonds sableux: valeur des résultats obtenus par la méthode du ${ }^{14}$ C. Cah O.R.S.T.O.M., Sér Océanogr 11:317-348

Posey MH (1988) Community changes associated with the spread of an introduced seagrass, Zostera japonica. Ecology 69:974-983

Posey MH, Wigand C, Stevenson JC (1993) Effects of an introduced aquatic plant, Hydrilla verticillata on benthic communities in the upper Chesapeake Bay. Estuar Coast Shelf Sci 37:539-555

Editorial responsibility: Kenneth Tenore (Contributing Editor), Solomons, Maryland, USA
Posey MH, Alphin T, Powell C (1997) Plant and infaunal communities associated with a created marsh. Estuaries 20: 42-47

Rader DN (1984) Salt-marsh benthic invertebrates: smallscale patterns of distribution and abundance. Estuaries 7:413-420

Ratchford SG (1995) Changes in the density and size of newly settled clams in Willapa Bay, WA, due to the invasion of smooth cordgrass Spartina alterniflora Loisel. MS thesis, University of Washington, Seattle, WA

Ruiz GM, Carlton JT, Grosholz ED, Hines AH (1997) Global invasions of marine and estuarine habitats by non-indigenous species: mechanisms, extent, and consequences. Am Zool 37:621-632

Snelgrove PVR (1999) Getting to the bottom of marine biodiversity: sedimentary habitats. BioSci 49:129-138

Snelgrove PVR, Blackburn TH, Hutchings PA, Alongi DM and 7 others (1997) The importance of marine sedimentary biodiversity in ecosystem processes. Ambio 26:578-583

Snelgrove PVR, Austen M, Boucher G, Heip C and 5 others (2000) Sediments-up and water column-down: linking biodiversity above and below the marine sediment-water interface. BioSci 50:1076-1088

Spicher D, Josselyn M (1985) Spartina (Gramineae) in northern California: distribution and taxonomic notes. Madroño 32:158-167

Stanczak M, Keiper JB (2004) Benthic invertebrates in adjacent created and natural wetlands in northeastern Ohio, USA. Wetlands 24:212-218

Talley TS, Levin LA (1999) Macrofaunal succession and community structure in Salicornia marshes of southern California. Estuar Coast Shelf Sci 49:713-731

Talley TS, Levin LA (2001) Modification of sediments and macrofauna by an invasive marsh plant. Biol Inv 3:51-68

Thompson JK (1982) Population structure of Gemma gemma in South San Francisco Bay, with a comparison to some northeastern United States estuarine populations. Veliger 24:281-290

Thompson DQ, Stuckey RL, Thompson EB (1987) Spread, impact and control of purple loosestrife (Lythrum salicaria) in North American wetlands. Fish Wildl. No. 2. US Department of Interior, Fish and Wildlife Service, Washington, DC

Wardle WJ, Minello TJ, Webb JW, Wu T, Jewett-Smith JJ (2001) Algal pigments, meiofauna, and macrofauna from two edaphic salt marsh microhabitats in Galveston Bay, Texas, USA. Wetlands 21:474-483

West DL, Williams AH (1986) Predation by Callinectes sapidus (Rathburn) within Spartina alterniflora (Loisel) marshes. J Exp Mar Biol Ecol 100:75-95

Whitlatch RB (1977) Seasonal changes in the community structure of the macrobenthos inhabiting the intertidal sand and mudflats of Barnstable Harbor, Massachusetts. Biol Bull (Woods Hole) 152:275-294

Zimmerman RJ, Minello TJ (1984) Fishery habitat requirements: utilization of nursery habitats by juvenile penaeid shrimp in a Gulf of Mexico salt marsh. In: Copeland BJ, Hart K, Davis N (eds) Research for managing the nation's estuaries. Proceedings of a Conference, Raleigh, NC, p 371-383

Zipperer VT (1996) Ecological effects of the introduced cordgrass, Spartina alterniflora, on the benthic community structure of Willapa Bay, Washington. MS thesis, University of Washington, Seattle, WA

Submitted: November 18, 2003; Accepted: November 4, 2004 Proofs received from author(s): April 1, 2005 